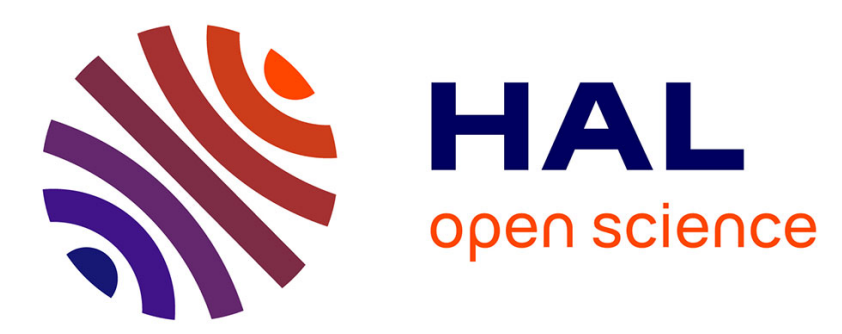

\title{
The role of compaction contrasts in sediments in décollement initiation in an accretionary prism
}

Hugues Raimbourg, Kohtaro Ujiie, Achim Kopf, Toshio Hisamitsu, Yozo

Hamano

\section{- To cite this version:}

Hugues Raimbourg, Kohtaro Ujiie, Achim Kopf, Toshio Hisamitsu, Yozo Hamano. The role of compaction contrasts in sediments in décollement initiation in an accretionary prism. Marine Geology, 2011, 282 (3-4), pp.188-200. 10.1016/j.margeo.2011.02.011 . insu-00587331

HAL Id: insu-00587331

https://hal-insu.archives-ouvertes.fr/insu-00587331

Submitted on 10 May 2011

HAL is a multi-disciplinary open access archive for the deposit and dissemination of scientific research documents, whether they are published or not. The documents may come from teaching and research institutions in France or abroad, or from public or private research centers.
L'archive ouverte pluridisciplinaire $\mathbf{H A L}$, est destinée au dépôt et à la diffusion de documents scientifiques de niveau recherche, publiés ou non, émanant des établissements d'enseignement et de recherche français ou étrangers, des laboratoires publics ou privés. 
The role of compaction contrasts in sediments in décollement initiation in an accretionary prism

Hugues Raimbourg ${ }^{\mathrm{a}-\mathrm{b}}$, Kohtaro Ujiie ${ }^{\mathrm{a}}$, Achim Kopf ${ }^{\mathrm{c}}$, Toshio Hisamitsu ${ }^{\mathrm{d}}$, Yozo Hamano, Saneatsu Saito ${ }^{a}$, Masataka Kinoshita ${ }^{a}$

(a) JAMSTEC, Yokosuka, Japan

(b) Institut des Sciences de la Terre d’Orleans, University of Orléans, France

(c) MARUM, Bremen, Germany

(d) Kochi Core Center, Japan

Corresponding author: hugues.raimbourg@univ-orleans.fr

\begin{abstract}
To understand how décollements develop into the pristine sedimentary succession entering subduction zones, we have performed mechanical tests on samples from the sediment column entering the Nankai accretionary prism, Japan (ODP site 1173). Both poroelastic compliance and plastic shrinkage upon application of a large effective pressure sharply decrease with depth in a $\sim 100 \mathrm{~m}$-thick domain in the upper section of the Lower Shikoku Basin unit, i.e. in a domain stratigraphically close to the actual
\end{abstract}


location of the décollement near the toe of the prism. These property contrasts provide a potential explanation for the outward migration of the décollement into the incoming sediments.

When approaching the deformation front, a given material particle is affected by an increase in stress, which has a component of vertical loading due to the deposition of overburden trench sediment, but also a component of lateral compression transmitted from the accretionary wedge. Depending on its initial mechanical state, the amount of lateral shortening in the incoming Nankai sediment column varies with depth and causes horizontal velocity gradients that concentrate into the mechanical transition zone (upper section of the Lower Shikoku Basin at appx. 450-550m depth) into which the décollement eventually propagates. Future work has to assess the role of this plastic deformation relative to other governing factors such as friction coefficient and excess pore pressure, both at Nankai and along other active margins.

\section{Introduction}

Convergent margins can be either non-accreting, where all the incoming sediment sequence is underthrust by subduction, or accreting, where part of these sediments are incorporated into a growing accretionary prism (Uyeda and Kanamori, 1979; Von Huene and Scholl, 1991). Along accreting margins, the fraction of incoming material 
accreted to the overriding plate is controlled by the position of the décollement, which is therefore a major factor in prism growth, dynamics and global mass balances.

The décollement can often be seismically imaged as a high amplitude, reverse polarity reflector (e.g. Moore et al. (1990) in Nankai, Shipley et al. (1990) in Costa Rica), interpreted as the interface separating high porosity/fluid pressure underthrust sediments from low porosity/fluid pressure accretionary prism material (Tobin and Saffer, 2009). The coexistence of these two independent hydrologic systems implies that the interface, or décollement, has larger permeability than the material above and below (Henry and Le Pichon, 1991). The décollement is therefore often considered as an highly fractured horizon, where the pore pressure is relatively high compared to surrounding material, as a result of channelized flow of deep fluid (Saffer and Bekins, 1998). In turn, high pore fluid pressure reduces the effective stress and promotes further fracturing or fault initiation.

Although there is an enhancement in deformation and fluid flow in a mature décollement, it is unclear how this discontinuity in physical properties of the seaward-migrating frontal thrust extends into material outboard of the deep-sea trench. In Barbados prism, the presence of a high-porosity, radiolarian-rich horizon (Moore et al., 1998; Moore, 2000) may explain décollement localization. On the other hand, such 
lithological heterogeneity is not relevant in Nankai area (Fig. 1), where both Upper Shikoku Basin (U.S.B.) and Lower Shikoku Basin (L.S.B.) units consist dominantly of hemipelagic silty mudstones (Shipboard Scientific Party, 2001b).

As detailed in section 2, alternative candidates for the controlling properties are permeability (2.1), shear strength (2.2) or yield strength (2.3). The two latter factors refer to the material mechanical state, which is usually assessed by geotechnical tests, i.e. rather by the stress necessary to trigger plastic deformation/slip than by the amount of strain for a given stress increment. In this manuscript we propose to reverse this point of view and to consider the finite strain affecting incoming material upon arrival into the prism. The amount of compaction versus depth constitutes a new possible controlling factor for décollement localization when considering the horizontal compression in the vicinity of prism toe. For the new model, we first consider the state of stress in the vicinity of the prism toe and describe, based on the analogy with cutting tool processes, how horizontal compression affects incoming material seaward of décollement tip and deformation front (section 3). We then assess the material response to horizontal compression using mechanical testing under isotropic loading conditions up to maximum of twice in-situ effective stress (section 4). We finally define a model combining the horizontal compression with the mechanical profile to propose a new 
mechanism of décollement localization based on the differential horizontal compaction of a sedimentary column approaching the Nankai prism (section 5).

2. Décollement localization: state of the art

\subsection{Permeability/pore fluid pressure hypothesis}

As the décollement is the surface where the shear localizes, its propagation into incoming material is favoured in horizons where the shear strength is reduced. The presence of high pore fluid pressure, which lower the shear strength, is believed to account for the formation of the protodécollement seaward of the Nankai prism toe (Le Pichon and Henry, 1992; Le Pichon et al., 1993). In their model, the rapid loading of low-permability hemipelagites by the deposition of high-permeability turbidites near the trench results in the development of a minimum in effective pressure below the turbidite-hemipelagite transition, which attracts décollement propagation (See also Discussion 6.3).

\subsection{Shear strength hypothesis}

In Barbados, the décollement corresponds to a relatively broad zone with high smectite content, while its lower limit coincide with a minimum in smectite (Deng and Underwood, 2001). Smectite is characterized by a low friction coefficient, as evidenced by shear experiments performed on clay as well as natural Nankai samples (Ashizuri 
transect) (Brown et al., 2003).

For western Nankai (Muroto transect), Brown et al. (2003) linked smectite content and low intrinsic friction with the location of the outward-growing frontal thrust. There is indeed a maximum in smectite content in Site 1173 in the upper section of L.S.B., at depths compatible with the décollement (Steurer and Underwood, 2005). Additional ring shear experiments on samples from the two sites of this study $(1173,1174)$ reveal a wide range of friction coefficients from $\mu=0.32-0.47$ in U.S.B. facies to values as low as $0.14-0.16$ in the décollement zone at site 1174 and 0.16 in the projected décollement depth at site 1173 (Kopf, unpublished data). The extension along strike of this minimum is nevertheless not completely clear, as in site 808 of the Muroto transect, the smectite content (Underwood et al., 1993) as well as experimentally-determined friction profiles (Kopf and Brown, 2003) are relatively smooth across the décollement.

\subsection{Cementation hypothesis}

Using site 1173 sediments as pristine material not yet affected by prism influence, one-dimensional consolidation tests revealed large variations in mechanical strength, possibly related to the presence of cement (Morgan and Ask, 2004; Spinelli et al., 2007). Within the shallower U.S.B, consolidation tests and XRD analysis illuminated the presence of silica cement (Karig, 1993; Spinelli et al., 2007), which is also indirectly 
inferred from the unusually large porosity of these sediments for their depth. Due to the increase in temperature with depth, this silica cement disappears at larger depths and samples from the uppermost section of the L.S.B. (391 and $425 \mathrm{mbsf}$ ), were shown to behave like uncemented sediment (Spinelli et al., 2007). Uniaxial (vertical) consolidation tests carried out on L.S.B. sediments in Site 1173 (476 mbsf), as well as in sites 1174 (Morgan and Ask, 2004) and 808 (Karig, 1993) below the décollement, yielded peak strengths much larger than vertical effective stress for hydrostatic conditions, interpreted as evidences of the presence of rock-strengthening cement of authigenic illite (Morgan and Ask, 2004; Sunderland and Morgan, 2004). This authigenic clay cement appears to disappear downward within the lower section of the L.S.B. (Ujiie et al., 2003; Sunderland and Morgan, 2004).

The strength profile of incoming sediment appears therefore as complex, as there are two cementing agents, silica and clays, distributed over distinct depth ranges, possibly not overlapping. Furthermore, S.E.M. analysis show evidence of clay cementation within material of the décollement in site 1174, which is absent in the deeper, underthrust sediments (Ujiie et al., 2003). The connection between décollement and material strength is therefore not straightforward.

\subsection{State of compaction of incoming sediments hypothesis}


While the mechanical state of incoming material is a priori a major control on décollement localization, one important process is the large porosity reduction affecting the sediment as it approaches the trench (e.g. Fig. 1) (Shipboard Scientific Party, 2001a; Screaton et al., 2002). The principal factor governing compaction is the progressive increase in overburden stress resulting from the deposition of a thick turbiditic trench wedge sequence. In addition, compressive horizontal stress active in convergent margins is likely to contribute also to compaction, although its amplitude and spatial distribution is poorly constrained. The lateral shortening has nevertheless large consequences on horizontal velocity and differential displacement of particles if heterogeneously distributed with depth in the incoming sediment column. Horizontal compaction constitutes therefore a potential new factor in décollement localization, whose validation requires to assess how (i) horizontal compression affects incoming material (section 3), (ii) the shortening resulting from this compression varies with depth (section 4) and (iii) velocity variations relate with horizontal compaction amplitude (section 5).

\section{Change in stress conditions near the prism toe}

\subsection{Force balance near prism toe}

In accretive margins, the material approaching the trench is eventually either accreted 
into the accretionary prism or underthrust beneath it (Fig. 2A). The décollement, i.e. the frontier between accreted and underthrust domains, is a mechanically weak zone, possibly because of high pore fluid pressure, so transmitted shear stresses are of low magnitude and the stress field is decoupled between accretionary prism and underthrust sequence (Westbrook et al., 1982; Taira et al., 1992; Le Pichon et al., 1993). The state of stress within the accretionary prism is at first order described by the critical Coulomb wedge theory (Davis et al., 1983; Dahlen, 1984, 1990). The wealth of low angle thrust faults visible on the seismic cross-sections of the outer wedge of Nankai accretionary prism (Moore et al., 2001; Moore et al., 2009) supports the idea that the prism is, in the long-term, in a critical compressional state with the maximum compressive stress close to horizontal (volume "In" of Fig. 2A; see also results of mechanical testing of samples from ODP site 808 (Feeser et al., 1993; Moran et al., 1993)), which sharply contrasts with the underthrust sequence, either free of contraction (Taira et al., 1992) or even stretched in the horizontal direction (Byrne and Fisher, 1990).

If the classical critical wedge solution accounts for many of prism features, it is not clear how lateral compression in the toe extends seaward (volume "Close" of Fig. 2A). In the vicinity of the prism toe, the principal forces at stake are: (1) Dragging by the subducting lithosphere, whose velocity is constant all over its surface, (2) shear stresses 
on the décollement and (3) compressive forces in the wedge. Because shear stresses on the weak décollement are of limited magnitude, the forces in the wedge (in position "In”, Fig. 2) must be transmitted seaward to be balanced by basal shear stresses, which implies that horizontal compression affects material seaward of the décollement tip. The second crucial point is that such compression must affect the whole sequence of incoming material (volume "Close”) and not only its upper section, as it is balanced by shear stresses on its base. Lateral compression vanishes far from the prism tip at the same pace as basal shear stresses diminish, until a far-off state (volume "Far", corresponding to site 1173), where the influence of the prism is negligible.

\section{2 Analogy with metal-cutting process}

Some insights on the stress state can be gained by regarding the analogy of classical metal cutting (Drucker, 1949) (Fig. 2C). Although timescale and lengthscale, as well as the mechanisms of deformation are completely different from granular materials entering a subduction zone, the geometry and the kinematic boundary conditions of the metal cutting process and frontal accretion are very similar. When considering the tool+chip=accretionary prism and metal layer=incoming sediment sequence being analogues, we find: (1) The velocity with respect to the tool is fixed as constant in the metal layer over its lateral and basal boundaries (Woon et al., 2008). This translates as 
constant convergence velocity all over the sediment sequence far off the trench and all over its base, as a result of dragging by underlying lithosphere. (2) Upon arrival on the tip (seaward end of the décollement) of the cutting tool (accretionary prism), an incoming column is split into two sections. While the velocity of the lower section is hardly affected, the upper section's velocity changes sharply as the material is incorporated into the chip (prism). In the sketches (Fig. 2B/C), the only difference lies in the fact that chip and tools remain distinct entities in metal cutting but are a single volume in prism accretion process.

From this analogy, a few essential insights on accretionary prism stress can be drawn from the abundant literature about material processing:

- Shearing and splitting of incoming material column results in the formation of a zone of high strain and stress, typically extending ahead of the tool (i.e. seaward of the décollement tip) over a distance of the order of a few times the tool edge radius. When taken into the subduction zone setting, this distance is equivalent to the thickness of accreted layer (Drucker, 1949; Kim et al., 1999; Liu and Melkote, 2007; Wu and Liu, 2009).

- The stress field within this region includes, in addition to shear parallel to the convergence direction, a component of horizontal compression, which may reach a 
magnitude similar to the order of the shear stresses (cf. the amplitude of the quantity labelled as “overpressures” in Woon et al. (2008)).

\section{Mechanical experiments on Nankai Trough samples}

\subsection{Experimental Procedure}

We sampled 12 small cylinders (diameter $\mathrm{x}$ height $=38$ x 11 17 mm) in Hole 1173A, orientated so that the cylinder base is vertical (i.e. parallel to the core axis) and the height is horizontal (Fig. 1D). These samples span an interval of 250-660 mbsf (meters below sea-floor), which includes the lower part of U.S.B. and most of the underlying L.S.B. and comprises the stratigraphic equivalent of the décollement (390-420 mbsf) (Fig. 1).

The mechanical tests consist of isotropic loading of the sample under controlled conditions of confining ( $\mathbf{P}_{\mathbf{c}}$ : oil) and pore pressure $\left(\mathbf{P}_{\mathbf{p}}\right.$ : de-ionized water) and monitoring the evolution of height using linear variable displacement transducers (LVDTs) (precision 1 micron) (Fig. 3).

The isotropic loading conditions chosen for our tests do not enable us to derive all mechanical (poroelastic and plastic) properties of the tested sample, hence we cannot estimate precisely the sample response to different, more complex loading conditions, such as the uniaxial loading (either horizontal or vertical) discussed hereafter. On the 
other hand, our experimental results can be considered as coarse indicators of the magnitude of the deformation to be expected, whatever the precise loading conditions, and we use them in this sense in the following. This assumption is further supported by our experimental measurements (Raimbourg et al., in press), showing that, at least in the poroelastic field, the mechanical anisotropy is very limited, so that measurements done in an arbitrary direction are to some extent representative of sample response in every direction.

As we do not monitor the volume of fluid flow in and out of the sample, we cannot precisely estimate pore volume changes and, hence, true compressibility. Nevertheless, for isotropic behavior, total volume/porosity variations can be assessed from uniaxial measurements of height variations as $\frac{\delta \phi}{1-\phi}=\frac{\delta \mathrm{V}}{\mathrm{V}_{0}}=3 \frac{\delta \mathrm{h}}{\mathrm{h}_{0}}$. Each experiment can be divided into a first, poroelastic phase, where the effective pressure $\left(\mathbf{P}_{\mathrm{eff}}=\mathbf{F}_{\mathbf{s}}-\mathbf{P}_{\mathbf{p}}\right)$ applied was kept low, and a second phase, where large effective pressures were applied to assess the plastic response of the material (Fig. 4).

For the sake of comparison between samples, every experiment lasted for two days, including the re-saturation phase. Tests were conducted at room temperature using de-ionized water. Changes in pore water composition may induce swelling of smectitic clays (Deng and Underwood, 2001), but as stressed by these authors, such swelling is 
only significantly large if smectite is the major constituent of the rock. In Hole 1173A, smectite relative abundance is generally below 30\% except in the upper section of L.S.B. where it is in the range 30-40\% (Brown et al., 2003). We thus consider this effect negligible. Furthermore, for swelling of clay to be significant, a large portion of in-situ pore water must be exchanged with external, de-ionized fluid - something we consider unlikely given the experimental setup: In our experiments where poroelastic deformation involves only a very small amount of porosity variations and fluid exchange, the largest fluid flow corresponds to sample plastic shrinkage, but in this case only expulsion of in-situ fluids rather than fluid exchange occurs (see also (Morgan and Ask, 2004). On this basis, we suppose that the use of de-ionized water does not induce large perturbations in the mechanical behavior of the tested samples, except maybe for desorption at some clay mineral surfaces at the sample edges.

Thorough coupling between the entire sample face and the tubing is ensured by channels cut within the holder end-caps and the insertion, on both sides of the sample, of a perforated steel disk and a flexible steel mesh (noted as "spacers" on Fig. 3). Two piezometers on both sides of sample holder monitor throughout the test the evolution in P-wave velocity of the sample (Fig. 3).

\subsubsection{Initial sample re-saturation}


In order to fully re-hydrate the samples in the oil-filled high-pressure vessel prior to testing, the confining pressure $\mathbf{P}_{\mathrm{c}}$ and pore fluid pressure $\mathbf{P}_{\mathrm{p}}$ are conjointly increased up to $\mathbf{P}_{\mathrm{e}} \sim \mathbf{M P a}$ and effective pressure $\mathbf{P}_{\mathrm{eff}}=\mathbf{0 . 2}-\mathbf{0 .} \mathbf{\mathrm { MPa }}$. The applied effective pressure $\mathbf{P}_{\text {eff }}$ is set to a value well below the in-situ effective pressure, estimated as

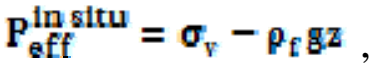
where $\sigma_{v}$ is the vertical stress of the overlying rock column (calculated using the bulk density profiles from shipboard moisture and density measurements (Shipboard Scientific Party, 2001b)), $\mathrm{z}$ its thickness and $\rho_{\mathrm{f}}$ the fluid density. The samples are exposed to these conditions for $12 \mathrm{~h}$ prior to the mechanical test.

This re-saturation procedure is similar to that of Morgan and Ask (2004), although there is a large time lapse ( $\sim 10$ years) between core recovery and laboratory testing in our case. Doubts concerning sample saturation and potential evaporation of pore water can be almost excluded in spite of their long stay in the IODP core repository as:

- Height variations during this saturation phase are limited to a few tens of microns, i.e. a few per mil

- Porosity measured using oven-drying to assess water content (Blum, 1997) and grain density determined on-board by pycnometer for nearby samples is, to a few percent, the 
same as on-board measurements carried out after coring (Fig. 5).

\subsection{2 $1^{\text {st }}$ experimental stage}

After the re-saturation phase, several steps of varying $\mathbf{P}_{\text {eff }}$ were applied within a range below $\mathrm{P}_{\text {eff }}^{\text {insitu }}$. We repeated these operations for several values of confining pressure, both to check the reversibility of the deformation and to assess a potential effect of the confining pressure on poroelastic moduli. In the $\mathbf{P}_{\text {eff }}$ range from 0.5 to $1.5-3 \mathrm{MPa}$ (the upper limit of the range is dictated by in situ conditions for shallow samples), sample height variations are almost linear, enabling us to derive the poroelastic compliance:

\section{$\frac{1}{h_{0}} \frac{\partial h}{\partial P_{e f f}}$}

\subsection{3 $2^{\text {nd }}$ experimental stage}

During the second phase, $\mathbf{P}_{\mathrm{o}}$ was fixed to in situ conditions $\left(\mathbf{P}_{\mathrm{e}}=\boldsymbol{\sigma}_{\mathrm{h}}\right)$ and we applied cycles of $\mathbf{P}_{\text {eff }}$ first increasing in amplitude to a value $\mathrm{P}_{\text {eff }}^{\operatorname{mgx}} \approx 2 \mathrm{P}_{\text {eff }}^{\text {in situ }}$, then of decreasing amplitude back to initial conditions. This procedure of changing $\mathbf{P}_{\text {evf }}$ through $\mathbf{P}_{\mathbf{p}}$ variations differs from typical experiments (e.g. Morgan and Ask (2004)) where changes in $\mathbf{P}_{\mathrm{eff}}$ are controlled through $\mathbf{P}_{\mathrm{c}}$ variations for a fixed $\mathbf{P}_{\mathrm{p}}$. Its justification lies in the concomitant estimation of P-wave velocity using the piezometers shown in Fig. 3, for conditions as close as possible to in-situ ones (See Raimbourg et al. 
(in press).

In some of the samples, plastic yield, characterized by a large and rapid shrinkage, was observed for $\mathbf{P}_{\text {eff }}$ in the range $\mathbf{P}_{\text {eff }}^{\text {mgx }}-\mathbf{2} \mathbf{P}_{\text {eff }}^{1 \text { nsitu }}$. To estimate this potential plastic deformation, we assessed the extent of the height reduction as $\overline{\mathbf{h}_{0}}$ for each sample, where $\mathbf{h}_{\mathbf{0}}$ is the initial height and $\mathbf{\Delta} \mathbf{h}^{*}$ is the height variation between $\mathrm{P}_{\text {eff }}^{\text {instu }}$ and $\mathbf{P}_{\text {eff }}^{\operatorname{mgax}}$

The time necessary to reach "perfect" equilibrium is much larger than in a typical experimental time-scale, because of slow plastic deformation. Upon application of a large $\mathbf{P}_{\mathbf{a f f}}$, we observed nevertheless a strong decrease in deformation rates, so that, over a few hours, one can consider that some equilibrium, at least with respect to initial, rapid deformation mechanisms, is reached. Similarly, for an initially large $\mathbf{P}_{\text {eff }}$ applied while the volume of fluid in the external circuit connected to the sample is kept constant, $\mathbf{P}_{\text {eff }}$ decreases exponentially towards an asymptotic value. We considered equilibrium was reached based on such asymptotic $\mathbf{P}_{\text {evf }}$ evolution, resulting in durations of at most a few hours for the largest $\mathbf{P}_{\mathrm{sff}}$ increments in the slowest experiments. Based on the above, we defined the duration of each test to be a full two days.

Upon application of large $\mathbf{P}_{\text {eff }}$, we also checked that the time necessary for equilibrium is much larger than the time necessary for the pressure to be transmitted through the 
sample. The latter was estimated by a test similar to the pulse-decay method to determine permeability (Brace et al., 1968), i.e. by applying a differential fluid pressure between upper and lower sample surface and measuring its decrease with time.

\subsection{Results and interpretation of the tests}

\subsubsection{Experimental mechanical state profile}

The poroelastic compliance $\frac{1}{\mathbf{h}_{0}} \frac{\partial \mathbf{h}}{\partial \mathrm{P}_{\text {eff }}}$, determined in the horizontal direction, displays a non-linear trend of decrease with depth (Fig. 6B). A large decrease in compliance by a factor of $>2$, is concentrated in the depth interval 450 550 mbsf, while both 250 450 mbsf and 550 650 mbsf intervals have roughly constant properties.

The sample shrinkage for a large $\mathbf{P}_{\text {eff }}$ applied, i.e. $\frac{\Delta \mathbf{h}_{0}}{\mathbf{h}_{0}}$, shows a similar trend of rapid decrease in the 450 550 mbsf interval despite some scatter (Fig. 6A): While samples from depths shallower than 450 mbsf are shortened by $2 \%$ to almost $10 \%$, the shortening of samples deeper than 550 mbsf is less than 1.5\%. This shortening includes both poroelastic and plastic deformation as $\mathbf{P}_{\mathrm{eff}}$ is increased from $\mathbf{P}_{\mathrm{eff}}^{\text {insitu }}$ to $2 \mathbf{P}_{\text {eff }}^{\text {In situ }}$. However, due to the overall relatively low values of both compliance and $\mathrm{P}_{\text {eff }}^{\text {in situ }}$, most of the sample shortening $\frac{\Delta \mathbf{h}^{*}}{\mathbf{h}_{10}}$ corresponds to plastic deformation. In summary, both poroelastic compliance and plastic deformation amplitude expresses a large variation in material state around 450 550 mbsf, which we hence define as the 
"transitional domain" (see below, and Fig. 6).

\subsubsection{Comparison with previous results}

Karig (1993) and Morgan and Ask (2004) carefully carried out uniaxial consolidation tests of core samples from prism toe below the décollement (samples from ODP cores 808-74, 808-85, 1174-78), off the deformation front below the turbiditic deposits (DSDP cores 582-68, 582-73) and further off the prism (ODP core 1173-51). These tests enabled to measure and plot the evolution of differential stress $\Delta \sigma=\sigma_{\text {vert }} \quad \boldsymbol{\sigma}_{\mathrm{hor}}$ with increase in mean effective stress $\mathbf{P}_{\text {sfl }}$ (Morgan and Ask, 2004), highlighting the complexity of the compaction, i.e. post-yield behavior, decomposed into several distinct phases.

All these experiments concern relatively deep samples with respect to the domains we consider here, as the shallowest, core $1173-51$ at 476 mbsf, is already in what we defined as the transitional domain of depth, where plastic shrinkage gets limited (Fig. 6). Some of their samples were recovered far off the prism or below the décollement at the toe, so that the material has been variously affected by prism-related deformation and consolidation and is difficult to be compared to our data. For four samples one can nevertheless apply an approach similar to ours and consider the amount of strain for an experimentally applied vertical effective stress twice as large as in-situ value (estimated 
for hydrostatic pressure; see section 4.2.1 above). As a result, U.S.B. samples (DSDP cores 582-68, 582-73) with high porosity $(\sim 50 \%)$ are affected by vertical strains of 6-8\% (Karig, 1993), while samples with a lower porosity, 1173-51 ( 45\%) and 1174-78 ( $\sim 38 \%$ ) by $4.7 \%$ and $4 \%$, respectively (Morgan and Ask, 2004). The contrast in vertical strain is probably even larger, as actual $\mathbf{P}_{\text {eff }}^{\text {insitu }}$ (hence $2 \mathbf{P}_{\text {eff }}^{\text {insitu }}$ ) for sample 1174-78 is much lower than the value calculated assuming hydrostatic pore pressure (Morgan and Ask, 2004), so that the strain (4\%) is probably overestimated.

In summary, similarly to our study, the amplitude of the plastic shrinkage strongly decreases with depth and is, in deeper and less porous samples, half of its value in shallower and more porous material.

\section{Model of differential horizontal compaction}

\subsection{Velocity reduction from horizontal shortening}

Both the schematic stress analysis of the prism toe area as well as the analogy with metal-cutting processes show that the sedimentary column approaching the prism toe is affected by lateral compression ahead of the décollement tip. The lateral shortening enhances porosity reduction in the sedimentary column, which is already affected by the rapid loading of trench turbidites. The effect of lateral compression is nevertheless not the same as vertical loading, as in the former case the shortening is parallel to rock 
velocity (See Appendix). For mass conservation sake, in steady state regime, as the flux of solid material through a given surface must be constant laterally (i.e. in the direction parallel to convergence), horizontally shortened (hence denser) material at the trench has to move more slowly than in its initial position far off the trench. In other words, the change in porosity associated with lateral shortening has to be compensated by a velocity decrease.

The porosity decrease associated with compaction as the sedimentary column approaches prism toe can be defined as

\section{$\Delta \phi=\Delta \phi_{\text {vert }} \mid \Delta \phi_{\text {hor }}$}

where $\Delta \phi_{\text {vert }}$ is the porosity decrease corresponding to the (virtual) case where only vertical loading occurs and $\Delta \phi_{\text {hor }}$ the additional decrease in porosity resulting from lateral compression.

The progressive reduction in velocity associated with incipient lateral compression for material moving from a position off the prism $\left(\mathbf{x}=0, \phi \mathbf{v} \phi_{\mathbf{0}}, \mathbf{v} \mathbf{v} \mathbf{v}_{0}\right)$ to the trench $\left(\mathbf{X}=\Delta \mathbf{X}, \phi=\phi_{0}-\Delta \phi, \mathbf{v}=\mathbf{v}(\mathbf{\Delta X})\right.$ ) can be estimated as $v(\Delta X)-v_{0}=v_{0} \frac{\Delta \phi_{\text {liop }}}{1-\phi_{0}}$

Where $\Delta \phi_{\text {hor }}$ is the (negative) porosity reduction from lateral shortening, assessed at trench (i.e. for $\mathbf{x}=\Delta \mathrm{x}$ ) and in the limit $|\Delta \phi| \ll \phi_{\mathbf{0}}$. 


\subsection{Application of differential compaction to Nankai Trough}

Despite the fact that the loading conditions in experimental and actual settings are much different, we postulate that the large differences obtained by isotropic loading are somehow significant of some "general" material behavior and are to some extent indicative of the material response to any loading path, in particular the complex, 3-dimensional loading active near prism toe.

Based on our results, the sedimentary column entering the trench can be modeled as composed of a shallow domain (above 450 mbsf), easily compactable, a deep domain (below 550 mbsf) more resistant to compaction, and a relatively thin transitional domain around 450 550 mbsf, in the upper section of the L.S.B. unit, where mechanical properties change sharply.

This bi-layered material, when affected by vertical loading and horizontal compression, undergoes some lateral shortening scaled by its resistance to compaction: $\Delta \Phi_{\mathrm{hor}}$ in the lower layer can be neglected with respect to the upper one. Accordingly, velocity is constant in the lower layer while it is reduced in the upper layer, resulting in differential displacement and strain distribution in the transition layer (Fig. 7).

In order to estimate this strain, we make the following assumptions:

- The thickness of the transition layer between these 2 layers is of the order of $100 \mathrm{~m}$ 
$(\Delta \mathrm{h}=100 \mathrm{~m})$

- The porosity decrease associated with lateral shortening $\Delta \phi_{\text {hor }}$ in the upper layer over a distance of $1 \mathrm{~km}$ seaward of the décollement tip $(\Delta \mathrm{\Delta x} \approx \mathbf{1} \mathrm{km})$ is of the order of $1 \%$, for an initial porosity $\left.\phi_{0} \approx 50 \% \quad \frac{\Delta \phi_{\text {hor }}}{\left(1-\phi_{0}\right.} \approx-2 \%\right)$.

Then the shear deformation accommodated by the transition layer can be estimated as (See Appendix)

$\varepsilon_{\mathrm{xz}}=\frac{\Delta \mathrm{X}}{\Delta \mathrm{h}}\left(-\frac{1}{2} \frac{\Delta \phi_{\text {hop }}}{1-\phi_{0}}\right) \approx 10 \%$

This large value shows that even a small component of "horizontal compaction", of the order of $1 \%$, may result in large shear strain within the transition zone in the upper section of L.S.B., which in turn may attract the décollement propagation.

\section{Discussion}

\subsection{Rock properties: cementation and critical porosity}

\subsubsection{Cement distribution}

The complex pattern of cement distribution in Nankai incoming sediments, as highlighted by geomechanical testing and other data (see 2.3, Spinelli et al. (2007) and Raimbourg et al. (in press)), appears at first sight at variance with our results: the porous material of U.S.B. where we observed the most intense compaction, show evidences for silica cementation. Such contrasting behavior may be seen in the light of the $\mathbf{P}_{\text {eff }}$ 
exceeding $\mathrm{P}_{\mathrm{eff}}^{\text {insitu }}$ we applied, which may have triggered breakage of silica intergranular bonds and, subsequently, favored porosity collapse. Broken bonds and relative low porosity have already been described in décollement rocks of Site 1174 (Ujiie et al., 2003). In that respect, rather than showing variations in strength, the plastic deformation we measured for high $\mathbf{P}_{\mathrm{eff}}$ may indicate that the sample initial condition is far from normal consolidation state, most likely owing to the presence of cement that maintains the porosity at anomalously large value. Based on this hypothesis, shallow samples with large plastic shrinkage have large initial porosities that result from the presence of cement. The heterogeneous distribution of cement may also explain the large scatter in experimental compaction of these shallow, deformable samples. On the contrary, samples recovered at larger depth, where cement is absent or rare, have a normal porosity with respect to their depth, so a much lower capacity to shrink once large effective stresses are applied.

This apparent paradox, where our shallow deformable domain is actually the one where cement is present, is compatible with the anisotropy of magnetic susceptibility (AMS) profile (Fig. 8) that was related to bulk strain (Borradaile and Henry, 1997). The vertical compaction fabrics, expressed by the magnetic parameter F (Hrouda, 1982), low throughout the U.S.B., is higher in the uppermost L.S.B., decreases down to $400 \mathrm{mbsf}$ 
then starts increasing again. This reversal in compaction trends around 400 mbsf, may somehow correspond to the lower limit of the cement zone within the L.S.B., with deeper sediments much more affected by vertical compaction than shallower, more resistant ones. Accordingly, the capacity to shrink in response to horizontal compression when approaching the prism toe is much reduced in the uncemented, lower section of the L.S.B. compared to shallower sediments. This inevitably results in the differential strain patterns observed in the mechanical transition zone at the top of the L.S.B. - a fact that very likely contributes to décollement localization in the incoming sequence.

\subsubsection{Critical porosity and time-scale of compaction}

The porosity corresponding to the transition in mechanical behavior spans a porosity range of $42-46 \%$ (See Fig. 1 and Raimbourg et al. (in press)), i.e. close to the "critical porosity" where physical properties strongly vary and close-packing of grains prevails (Nur et al., 1998), although this value of the critical porosity is defined for sandstones and may not apply directly to the clay-rich material considered here.

The compaction processes for a porosity exceeding close-packing structure require only the displacement and rearrangement of individual grains, i.e. very little time. In contrast, compaction and further porosity decrease for a material already closely packed is not achieved by grain rearrangement but requires processes such as pressure dissolution and 
precipitation. The time-scale of compaction is, therefore, much longer for chemical processes to operate and the porosity loss for a given stress increment is much lower.

\subsection{Distribution of compaction near prism toe}

\subsubsection{Evidences for horizontal compaction}

On the basis of the correlation of logging-while-drilling (LWD) signals between adjacent sites, Hunze and Wonik (2007) were able to assess the porosity variations, for a given sedimentary sequence, from a reference site far from the trench to positions within the prism. As a result, the depth-averaged amplitude of the total (vertical and lateral) porosity decrease is in the range of $10 \%$ in the Barbados prism (comparison of Sites 1044 and 1045) and 25\% and 15\% for two distinct depth sections in Nankai prism (comparison of Sites 1173 and 808). Moreover, discriminating within this reduction the relative contribution of vertical/horizontal compaction, (Hunze and Wonik, 2007)'s results show that porosity loss due to lateral shortening is as large as $5-10 \%$, which represents a major contribution to total loss and is found in agreement with Saito and Goldberg (2001).

Similarly, quantitative rock fabric analysis, either based on anisotropy of magnetic susceptibility (AMS) analysis (Owens, 1993; Housen et al., 1996; Ujiie et al., 2003), X-ray goniometry (Behrmann and Kopf, 1993; Morgan and Karig, 1995) or anisotropy 
of P-wave velocity analysis (Brückmann et al., 1993), attest the presence of a component of lateral shortening parallel to the convergence velocity within the accretionary prism (i.e. in the material located above the décollement).

Although such results demonstrate the presence of horizontal shortening within the prism, they do not provide information as to how the lateral compressional field may extend seaward of the décollement tip. Few studies have attempted to examine this question. Along the Ashizuri transect in Nankai, seaward of the deformation front, there is a large porosity decrease (from $\sim 60 \%$ to $\sim 50 \%$ ) within the U.S.B. sediments between ODP hole 1177 (Shipboard Scientific Party, 2001a), 15 km from deformation front and DSDP site 582 (Bray and Karig, 1986), 3 km from deformation front. Although the larger part of this porosity decrease is probably the result of loading by overlying trench turbidites ( 100m-thick in 1177 and $\sim 550$ m-thick in site 582), there may be a contribution of tectonic shortening, but it has not yet been estimated. Unfortunately, in their kinematic model, Morgan et al. (1994) also assume that in the domain seaward of the deformation front only vertical compaction operates, preventing the quantification of horizontal shortening there.

The other example where two adjacent sites were drilled outboard of the décollement tip is Barbados (Moore, 2000): Here, the porosity profiles inferred from logging data 
(Shipboard Scientific Party, 1998) show that site 1048, located $\sim 3 \mathrm{~km}$ from the frontal thrust (assumed to roughly correspond to décollement tip), has not yet been affected by compaction with respect to the reference site 1044, located $\sim 6.5 \mathrm{~km}$ from tip. From this single example, it should be assumed that the horizontal compression related to the accretionary prism does not extend as far as $3 \mathrm{~km}$ from décollement tip, which is in agreement with the comparison with metal-cutting processes, where the width of the high-strain zone is shown to be of the order of a few times the off-scraped thickness, roughly $200 \mathrm{~m}$ in Barbados case.

The above examples do not provide unambiguous evidence with regard the assumption of the model. An additional difficulty is the amplitude of the porosity variations: The heterogeneous depth distribution, starting $1 \mathrm{~km}$ seaward of the décollement tip, of only $1 \%$ porosity decrease as a result of lateral shortening triggers large differential displacement and strain (See 4.2.2). However, this small amount of compaction is well within the range of scatter of porosity profiles determined either through core sample measurement or from P-wave velocity-porosity relationships and is therefore hardly detectable.

\subsubsection{Origin of horizontal compaction in the wedge}

As a corollary to its central assumption, our model provides an alternative explanation 
to the strong contrast in fabrics between material from the prism and the underthrust section (e.g. Westbrook et al. (1982), Taira et al. (1992) and Le Pichon et al. (1993)): Such fabrics are usually interpreted in terms of stress decoupling by the décollement, i.e. horizontal strain is only recorded above the décollement because only in this domain the horizontal tectonic compression is large. In this interpretation the strain patterns are the consequence of the décollement. As an alternative explanation we propose that these strain patterns may be partially inherited from the compaction of the sediments off the trench, where the décollement is not yet developed. In such a scenario, the décollement is the consequence rather than the cause of such differences in deformation patterns with depth.

\subsection{Pore pressure variations related to differential compaction and décollement}

\section{localization}

Excess pore pressure, i.e. pore pressure in excess of fluid hydrostatic pressure, is the driving force for compaction. Its amplitude is the result of the competition between sedimentary/tectonic loading (source of $\mathbf{P}_{\mathrm{p}}$ ) and outflow of fluid (sink of $\mathbf{P}_{\mathrm{p}}$ ), so that large excess pore pressure are favored by rapid loading and hindered flow of fluids (Shi and Wang, 1985, 1988). Pore pressure build-up in response to an increase in loading is controlled by the deformation of the skeleton of the rock/sediment: The material that we 
defined as easily deformable is unable to sustain a large increase in $\mathbf{P}_{\text {eff }}$ without compacting, so that an increase in the bulk load (i.e. in $\mathbf{P}_{\mathrm{c}}$ ) is instantaneously entirely converted into an increase in $\mathrm{P}_{\mathrm{p}}$. On the other hand, the deep, hardly deformable material of the lower section of L.S.B. can stand a large increase in $\mathbf{P}_{\text {eff }}$ without compacting, which implies that an increase in the bulk load is only partially transmitted to the pore fluid, resulting in a much smaller instantaneous pore pressure build-up. This contrasted compaction behavior has presumably a large impact on the evolution of the pore pressure profile during progressive loading, either vertical or horizontal. We consider in the following only vertical, sedimentary loading, but the conclusions would be qualitatively the same when taking horizontal compaction also into account.

Le Pichon and Henry (1992) and Le Pichon et al. (1993) interpreted the décollement localization within incoming hemipelagic sediments as a consequence of their rapid loading by more permeable trench turbidites, which results in the development of a high pore pressure zone/low effective stress zone in a horizon below the limit between trench and hemipelagic material.

Permeability profile is an essential feature of such model, as turbidites are required to be much more permeable than underlying hemipelagites, so that the pore pressure gradient is lower (Fig. 9). Another parameter of prime importance is how the increase in the 
sedimentary load (i.e. $\mathbf{P}_{\mathrm{c}}$ ) is transmitted to the pore fluid and converted into $\mathbf{P}_{\mathbf{p}}$ increase. The simplest approach, adopted by Le Pichon and Henry (1992) and Le Pichon et al. (1993) is to consider that the timescale of compaction is much smaller than timescales of (i) loading by sedimentation and (ii) fluid flow. In such a case, adjustment of the material porosity to the variations in the load $\mathbf{P}_{\mathrm{c}}$ as well as in the pore fluid pressure $\mathbf{P}_{\mathrm{p}}$ is instantaneous. Throughout its evolution towards the accretionary prism, all the points of the sedimentary column plot on a compaction curve $\phi-\mathbf{f}\left(\mathbf{P}_{\mathrm{eff}}\right)$ depending on the material. When assuming a rapid loading with respect to fluid outflow, the increase in $\mathbf{P}_{\mathbf{c}}$ affecting a given rock volume in the hemipelagite section is first entirely transmitted to the pore fluid (constant $\mathbf{P}_{\mathbf{e} \text { eff }}$ and $\phi$, increase in $\mathbf{P}_{\mathbf{p}}$ ) before outflow of fluid enables $\mathbf{P}_{\text {eff }}$ to increase and $\phi$ and $\mathbf{P}_{\mathrm{p}}$ to decrease (Fig. 9B).

Building from their model on, let's assume that the behavior of the low-permeability hemipelagite section with respect to compaction is not homogeneous and that it is constituted of an easily deformable upper section and a hardly deformable lower section.

When this column is submitted to a load increase $\mathbf{\Delta} \mathbf{P}_{\mathrm{a}}$ resulting from rapid turbidite deposition, within its shallower portion all the load increase is transmitted to the pore fluid (hence $\Delta \mathrm{P}_{\mathrm{p}}$ of the order of $\Delta \mathrm{P}_{\mathrm{q}}$ ). In contrast, in the deeper portion of the 
succession, a significant fraction of $\mathbf{\Delta} \mathbf{P}_{\mathrm{s}}$ is supported by the framework without being transmitted to the pore fluid (Fig. 9C).

As a result, within the low permeability hemipelagite, the compaction behavior governs the distribution of the pore pressure and the depth portion where $\mathbf{P}_{\mathbf{e f f}}$ is lowest is localized where the material is more easily compactable. This effect is even amplified within the U.S.B. part of the deformable section, as the anomalously large original porosities observed at site 1173 ((Shipboard Scientific Party, 2001a), Fig. 1C), probably related to silica cementation (Spinelli et al., 2007), provide a long-lasting source of pore fluid pressure before equilibration on the compaction curve once the cement got destructed by loading.

In conclusion, the difference in mechanical response to loading within the incoming sediment sequence has large consequences on the evolution in the $\mathbf{P}_{\mathbf{e f f}}$ profile as turbidites rapidly deposit on top of it. In the framework of the model developed by Le Pichon and Henry (1992) and Le Pichon et al. (1993), we propose that the minimum in $\mathbf{P}_{\text {sff }}$, developed in response to rapid overlying load increase, should lie within the highly porous and compactable U.S.B. material, therefore slightly offset with respect to actual décollement localization, which would imply that this phenomenon is not the prime control on outward migration of the frontal thrust. 


\section{Conclusion}

As Nankai accretionary prism is not a perfect wedge, closed by an acute angle, the horizontal compressive stresses active there must to some extent be transmitted seaward of the decollement tip and affect diffusely the whole incoming sedimentary sequence. As a consequence, the compaction affecting this material incorporates a part of horizontal shortening.

The response of samples collected at different depths within the incoming sequence to experimentally-imposed compaction show very contrasted behavior between shallower, easily compactable material and deeper, hardly compactable material. As a result, the amplitude of the horizontal shortening, as the sequence approaches the prism toe and is increasingly affected by horizontal compression, varies with depth. This differential horizontal shortening leads to differential displacement, hence strain, which localizes in the transitionary domain between easily and hardly deformable domains. This strain concentration eventually guides the propagation of the decollement within incoming material.

\section{Appendix}

The increase in stress results in compaction and porosity decrease in the material 
affected. To assess the effect of vertical and horizontal compaction, let's consider alternatively the simple cases where only vertical load or horizontal tectonic stresses increase.

\section{Vertical load increase:}

The vertical load increase triggers some porosity decrease $\Delta \phi$ that depends on the mechanical state of the material. As the material is laterally confined, for the sake of solid mass conservation, the porosity decrease is completely compensated by a decrease in thickness of the column without effect on the horizontal velocity (Fig. 10A).

\section{Horizontal stress increase}

Horizontal stress increase in the convergence direction also triggers a porosity decrease $\Delta \phi$ that depends on the mechanical state of the material (Fig. 10B). On the contrary to vertical compaction, the material is not confined in the vertical direction, so that horizontal compression is likely to induce some vertical expansion. Nevertheless, its extent is unknown, so as a minimum hypothesis we consider that the height of the sedimentary column is constant (vertical thickening of the column would result in an even larger velocity decrease than calculated hereafter).

In such case, the conservation of solid material requires that:

$$
\frac{\partial v}{\partial x}(1-\phi)-v \frac{\partial \phi}{\partial x}=0
$$


where $\mathrm{v}$ is the horizontal velocity.

For the sake of simplicity, we suppose that the porosity decrease $\Delta \phi$ (negative) is linear over a length $\Delta \mathrm{X} \quad\left(\Delta \phi=\phi_{\mathrm{X}=\Delta \mathrm{X}}-\phi_{\mathrm{x} \mathbf{m} 0}\right)$ :

$\frac{\partial \phi}{\partial \mathrm{x}}=\frac{\Delta \phi}{\Delta \boldsymbol{X}}$

If the variations in porosity are very low $\left(|\Delta \phi| \ll \phi_{0}, \phi \approx \phi_{0}\right)$, then mass conservation equations simplifies as:

$$
\frac{\partial \mathrm{v}}{\partial \mathrm{x}}-\frac{1}{1-\phi_{0}} \frac{\Delta \phi}{\Delta \mathrm{X}} \mathrm{v}=0
$$

yielding, for the horizontal velocity decrease:

$$
\left.v(x) v_{0} \operatorname{esp}^{\frac{\Delta \phi_{i}}{1-\phi_{0} \Delta x}} \mathrm{u}\right)
$$

which can be approximated by

$$
\begin{aligned}
& \quad v(x)=v_{0}\left(1+\frac{\Delta \phi}{1-\phi_{0}} \frac{x}{\Delta x}\right) \\
& \text { for }\left|\frac{\Delta \phi \phi_{0}}{1-\phi_{0}}\right| \ll 1 .
\end{aligned}
$$

In summary, the decrease in porosity associated with horizontal compaction is accommodated by a decrease in horizontal velocity.

\section{Double-layer horizontal compaction}

Now consider a sedimentary column constituted of two superposed layers, the upper one subjected to large plastic shrinkage when compressed, the lower one hardly deformable, and a transition layer in between (Fig. 10C). If this bi-material is subjected 
to horizontal compression, the upper material shrinks but the lower one does not, resulting in difference in horizontal velocity: while the lower one keeps the same velocity $\mathbf{v}_{\mathbf{0}}$ over $\Delta \mathrm{X}$, the upper material is progressively slowed down according to the law above.

The time necessary for the material to reach $\mathbf{x}=\Delta \mathrm{X}$ is

$\int_{0}^{\mathrm{T}} \mathrm{dt}=\int_{0}^{\Delta \mathrm{x}} \frac{\mathrm{dx}}{\mathrm{v}(\mathrm{x})}$, i.e.

$\mathbf{T}_{\text {low }}=\stackrel{\Delta \mathbf{X}}{\mathbf{v}_{0}}$ for the lower layer and

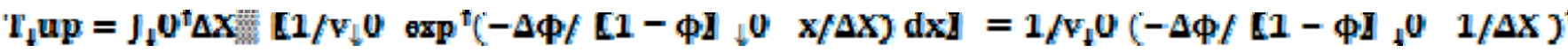

for the upper layer, which simplifies to

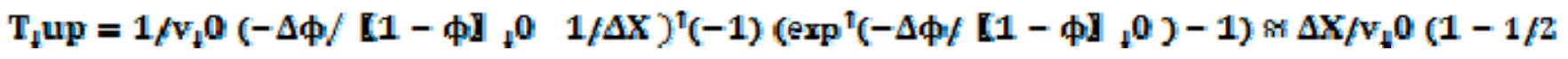
for $\left|\frac{\Delta \phi}{1-\phi_{Q}}\right| \ll 1$.

During the time $\mathbf{T}_{\mathrm{up}}$, a material point in the upper layer has moved a distance $\mathbf{\Delta x}$, while a material point in the lower layer has moved a distance $\mathbf{T}_{\mathrm{up}} \mathbf{v}_{0}$. As a consequence, the differential displacement $\Delta \mathbf{l}$, null for $\mathrm{x}=0$, increases up to, for $\mathrm{x}=\Delta \mathrm{x}$ $\Delta \mathbf{l}=\Delta \mathbf{x}\left(-\frac{1}{2} \frac{\Delta \phi}{1-\phi_{0}}\right)$

This differential displacement, accommodated within the transition layer of width $\Delta \mathrm{h}$, results for $\mathbf{x}=\mathbf{\Delta} \mathbf{X}$ in shear strain equal to: 


$$
g_{\mathrm{xz}}=\left(\frac{\Delta \mathrm{l}}{\Delta \mathrm{h}}\right) \propto \frac{\Delta \mathrm{X}}{\Delta \mathrm{h}\left(-\frac{1}{2} \frac{\Delta \phi}{1-\phi_{0}}\right)}
$$




\section{Figures}

Figure 1: (A) Map (Moore et al., 2005) and (B) interpreted cross-section of the Nankai trough off Muroto Cape (Morgan and Ask, 2004) showing locations of Sites 1173 and 1174. (C) Porosity profiles of Sites 1173 and 1174 (Shipboard Scientific Party, 2001a). In Site 1174 is also shown the outline of the porosity profile of Site 1173, scaled to fit the thickness variations between the 2 sites. (D) Distribution of samples from site 1173 used in mechanical tests, all cut as cylinders with horizontal revolution axis. U.S.B. (L.S.B.) for Upper (Lower) Shikoku Basin.

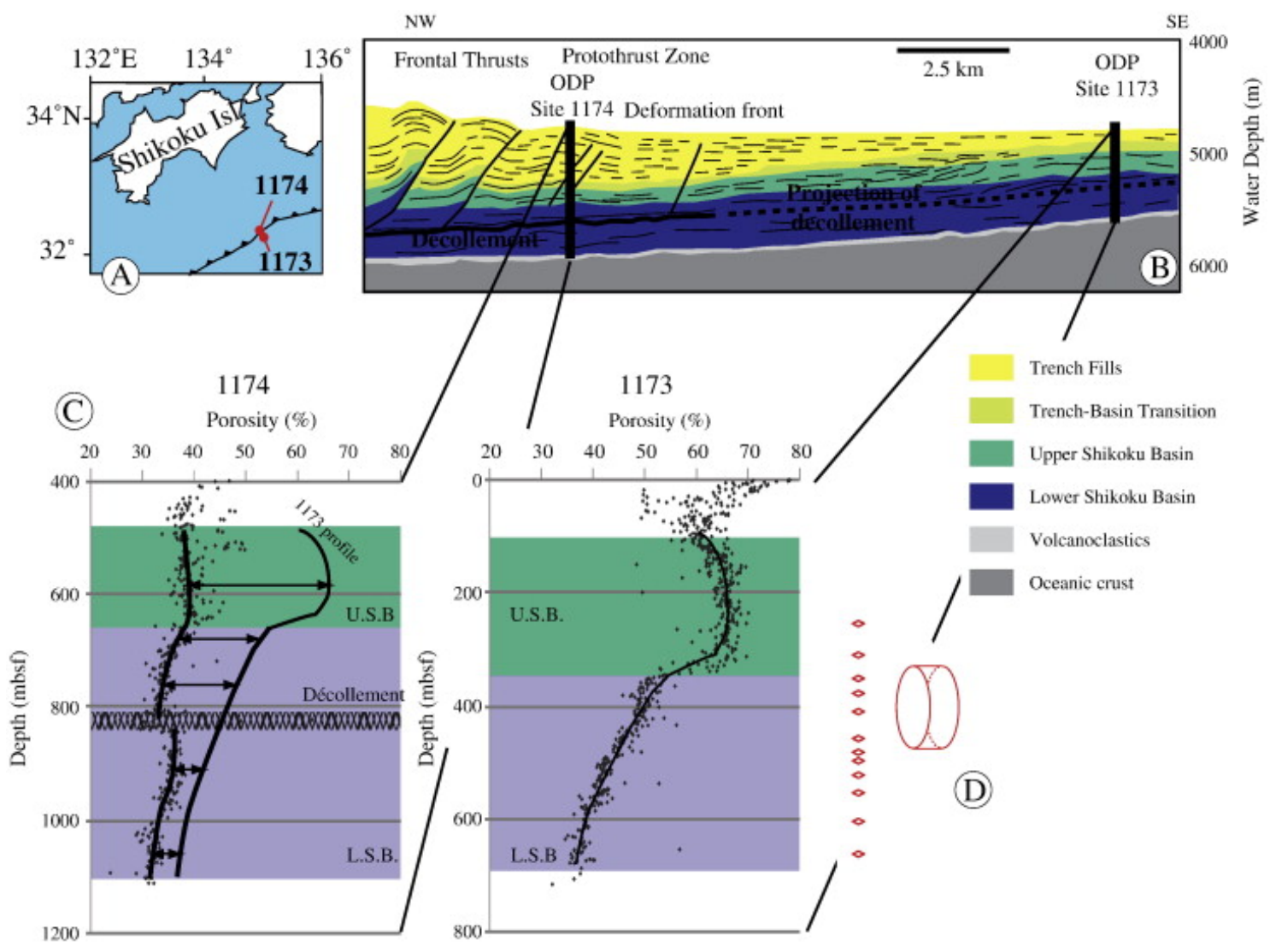


Figure 2: (A) Sketch of the forces applied on the mechanical discontinuities of the margin, as well as on a sedimentary column located either "Far", “Close” to the tip of or "In" the wedge. Splitting and shearing of incoming material implies the application of lateral compressive forces balanced by the basal shear related to dragging by the crust. (B) Top: Same model, but with kinematic boundary conditions (velocity defined with respect to the wedge): constant basal velocity imposed by plate convergence, null velocity on the backstop of the wedge over the décollement. Bottom: Analogy with the geometry and the kinematic boundary conditions (velocity defined with respect to the tool) of metal cutting process. Splitting and shearing of the metal plate by the tool results in the development of zone of high strain/deviatoric stress/pressure around and ahead of the tool edge. 

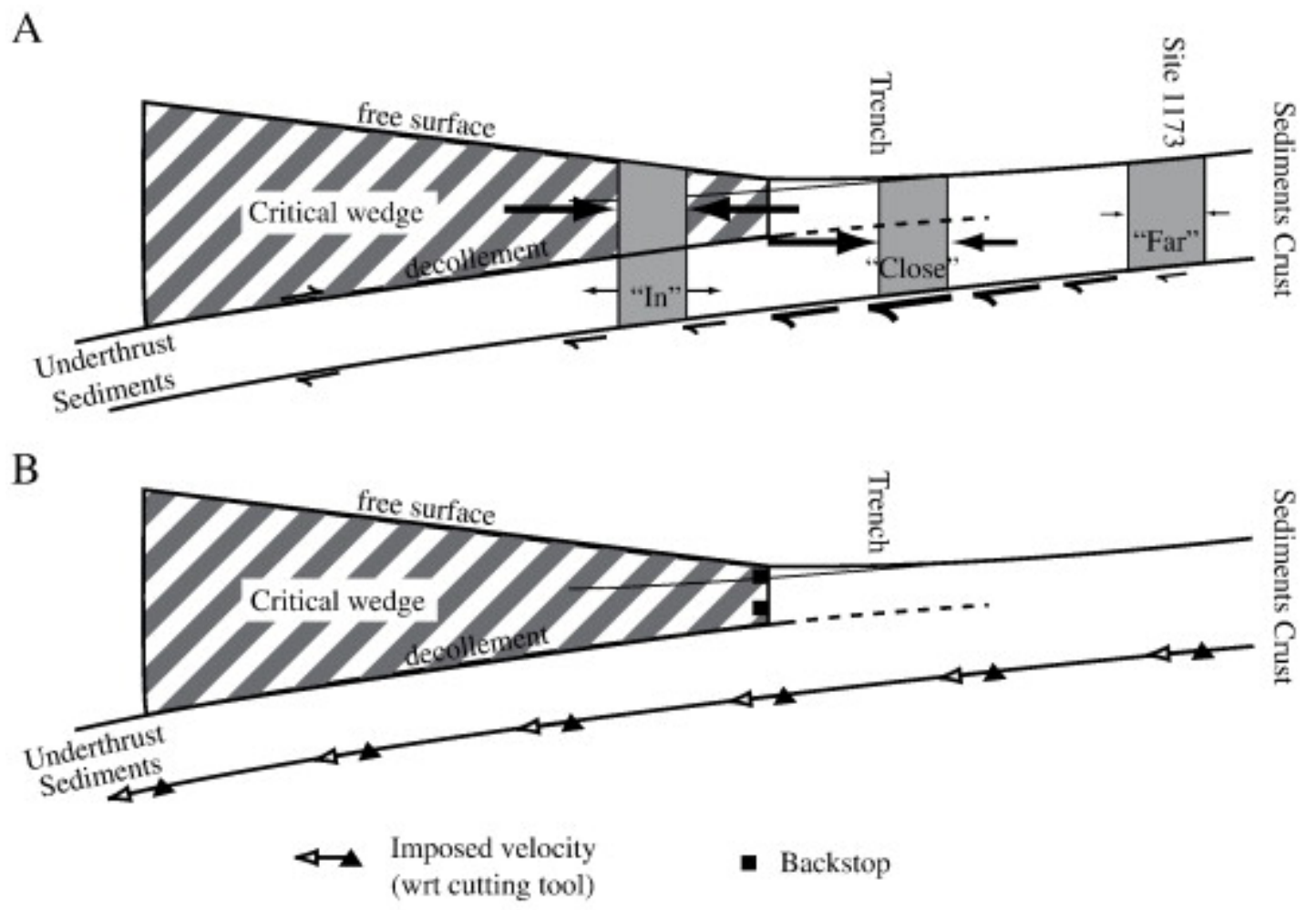

C Cutting tool equivalent to critical compressive wedge

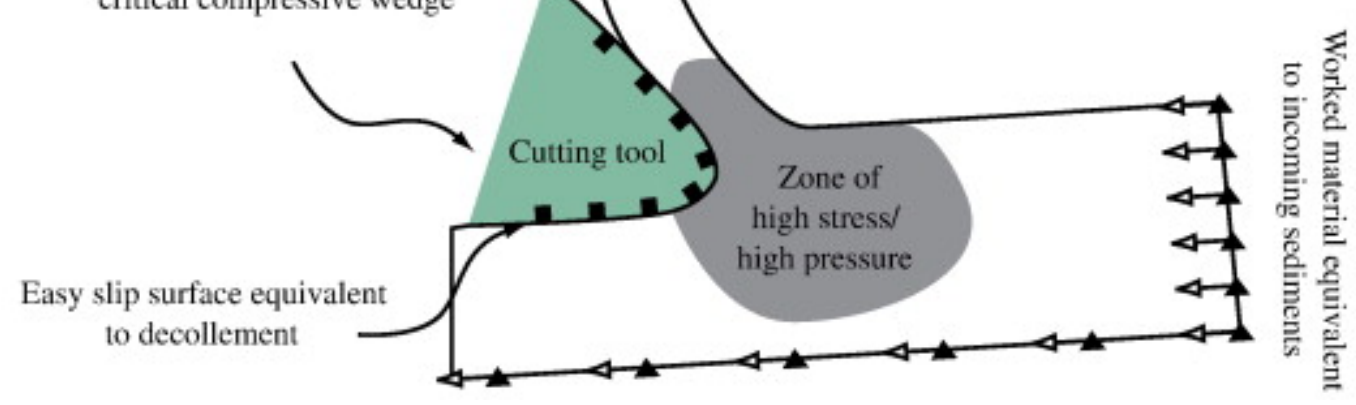


Figure 3: Experimental device of isotropic loading, where we measure variations in sample height $\boldsymbol{\Delta} \mathbf{h}=\left(\Delta \mathbf{h}^{\boldsymbol{t}}+\Delta \mathbf{h}^{\dagger=}\right) \ell^{\mathbf{2}}$ following $\mathbf{P}_{\mathrm{c}}$ and $\mathbf{P}_{\mathrm{p}}$ evolution. Piezometers placed on both holders' ends enable simultaneous measurement of P-wave velocity (See Raimbourg et al. (in press).

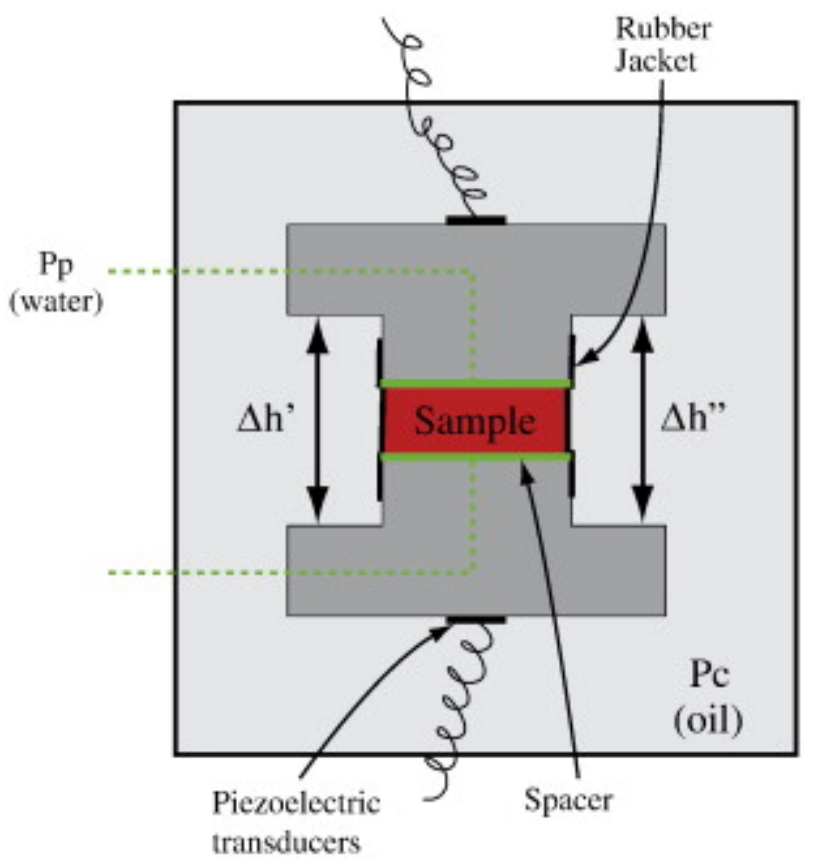

Figure 4: Typical evolutions of the sample height during one experiment, from $t_{0}$ to $\mathbf{t}_{\mathbf{f}}$ : In the first, poroelastic phase of the test, we applied several cycles of $\mathbf{F}_{\mathbf{e f f}}$ (=increasing then decreasing amplitude of $\mathbf{P}_{\text {evf }}$ ), while keeping $\mathbf{P}_{\text {evf }}$ to values smaller than $\mathrm{P}_{\text {eff }}^{\text {in situ }}$ (vertical thick bar). During this phase, variations of sample height are reversible and enable to derive the poroelastic compliance $\frac{1}{\mathbf{h}_{0}} \frac{\mathrm{\partial h}}{\partial \mathrm{P}_{\mathrm{eff}}}$ (=slope of height variations). In the second phase of the test, upon application of a large $\mathbf{P}_{\text {eff }}$, samples are affected by irreversible shrinkage, measured as the normalized height reduction 
$\Delta \mathbf{h}^{*}$ for $\mathbf{P}_{\text {eff }}$ increase from $\mathbf{P}_{\text {eff }}^{\text {insitu }}$ to $2 \mathbf{P}_{\text {eff }}^{\text {insitu }}$. $\Delta \mathbf{h}^{*}$ is very limited in deep sample (1173-55X) (A), while shallow sample (1173-28X) is affected by a rapid, very large and irreversible shrinkage (B) when $\mathrm{P}_{\text {eff }}$ reaches the range $\mathrm{P}_{\text {eff }}^{\text {insitu }}-\mathbf{2} \mathrm{P}_{\text {eff }}^{\text {insitu }}$. Please note that the height decrease (“Inside resetup”) near $\mathbf{t}_{0}$ for sample 1173A-55X is for most an artifact due to holder and filter setup and does not correspond to sample shrinkage.
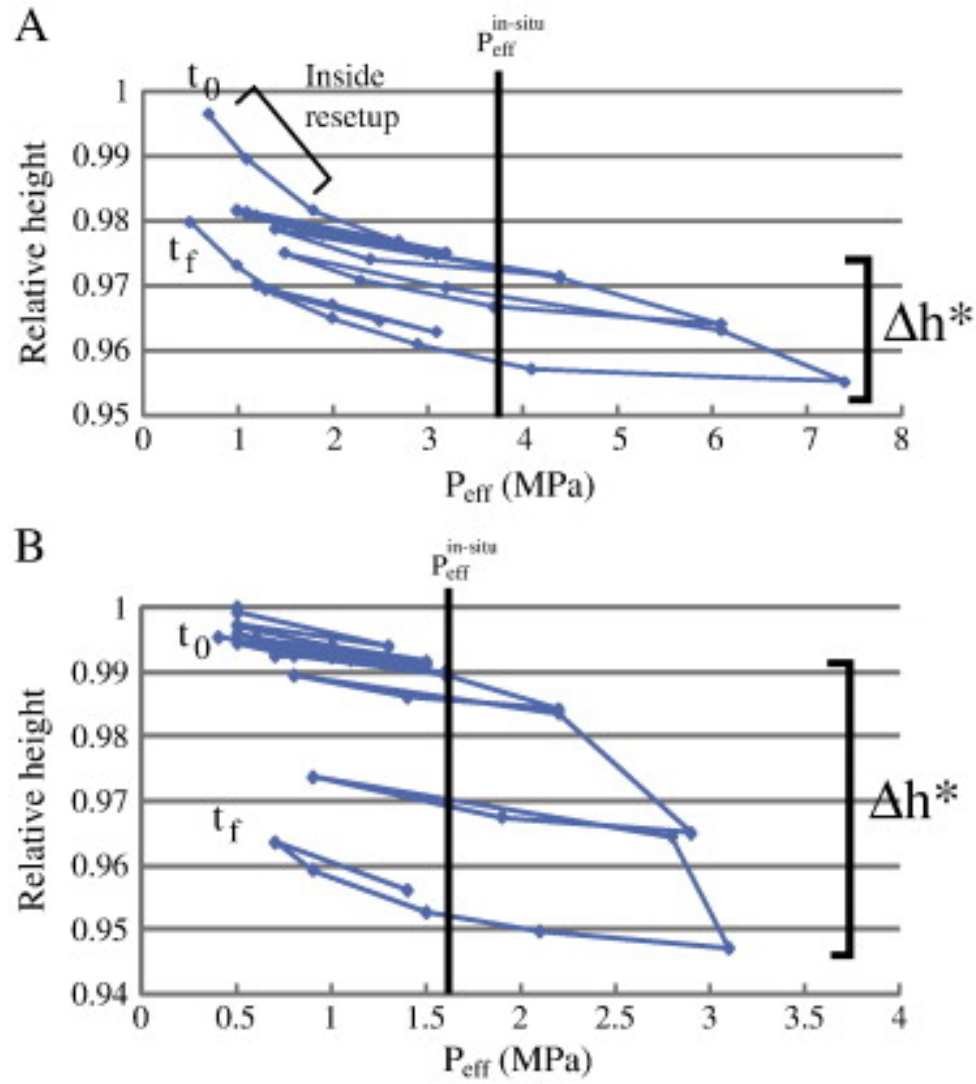
Figure 5: Comparison of on-board porosity determined just after sample recovery and porosity measured on our experimental material (see text for methods).

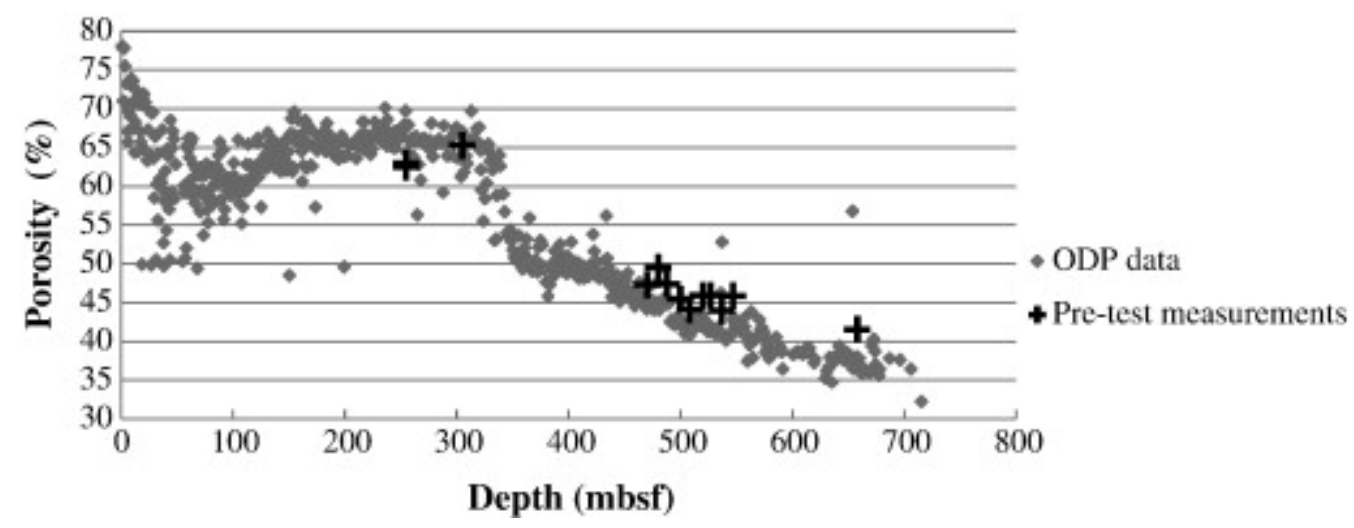

Figure 6: Mechanical properties of sediments from site 1173 determined in the horizontal direction: (A) Normalized height reduction $\mathbf{\Delta h}^{*}$ for $\mathbf{P}_{\text {sif }}$ increase from $\mathbf{P}_{\mathrm{eff}}^{\text {in situ }}$ to $2 \mathbf{P}_{\mathrm{eff}}^{\text {in situ }}$ and (B) poroelastic compliance $\frac{1}{\mathbf{h}_{0}} \frac{\partial \mathbf{h}}{\partial \mathbf{P}_{\text {eff }}}$, both expressing the sharp variations in mechanical state of the samples in the $450-550$ mbsf depth interval ("mechanical transition zone" in dark gray), located within the upper section of the L.S.B.. The multiple points for a given depth/sample in (A) correspond to measurements of the compliance repeated for each cycle of $\mathbf{P}_{\text {eff }}$ increase/decrease within the poroelastic field. 


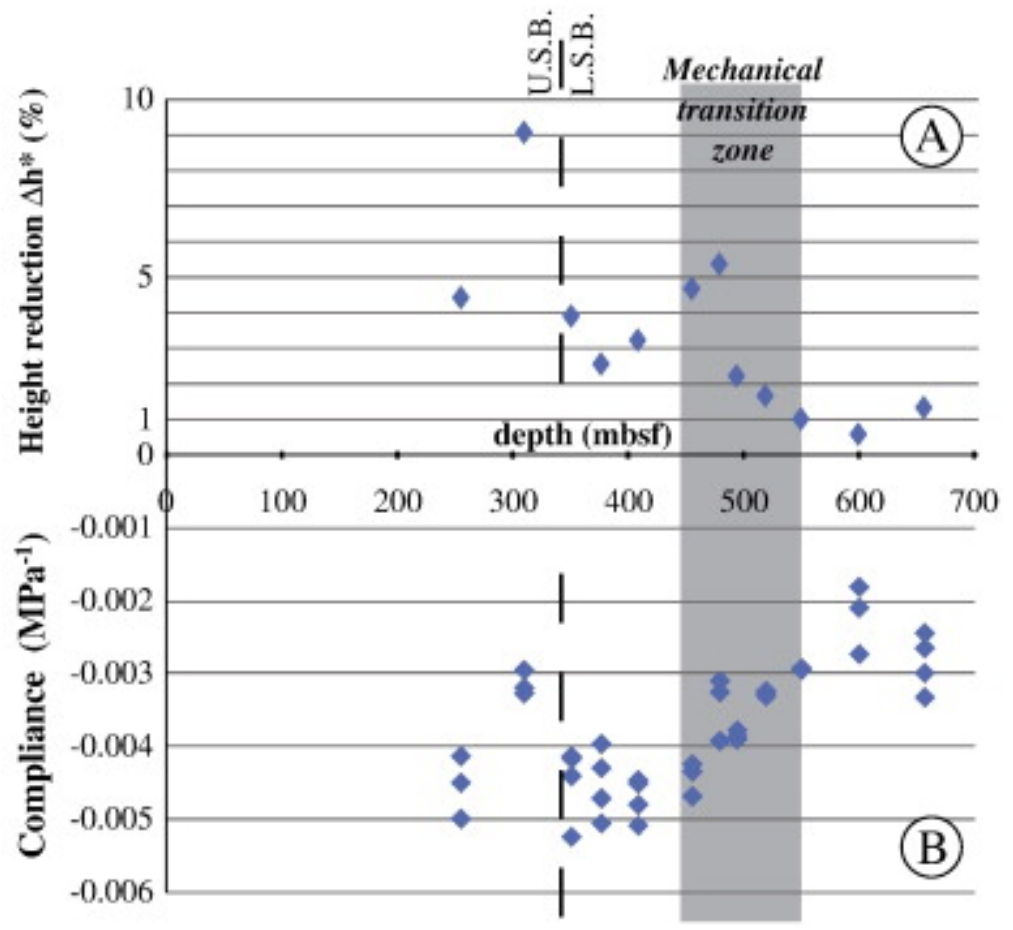


Figure 7: Model of décollement initiation based on the compaction of pristine, far-from-the-trench sediments: The difference in the intensity of compaction by horizontal tectonic compression between shallow, deformable sediments and deep, resistant ones, results in differential displacement and deformation that localize in the mechanical transition zone (upper section of L.S.B.) and control the décollement initiation.

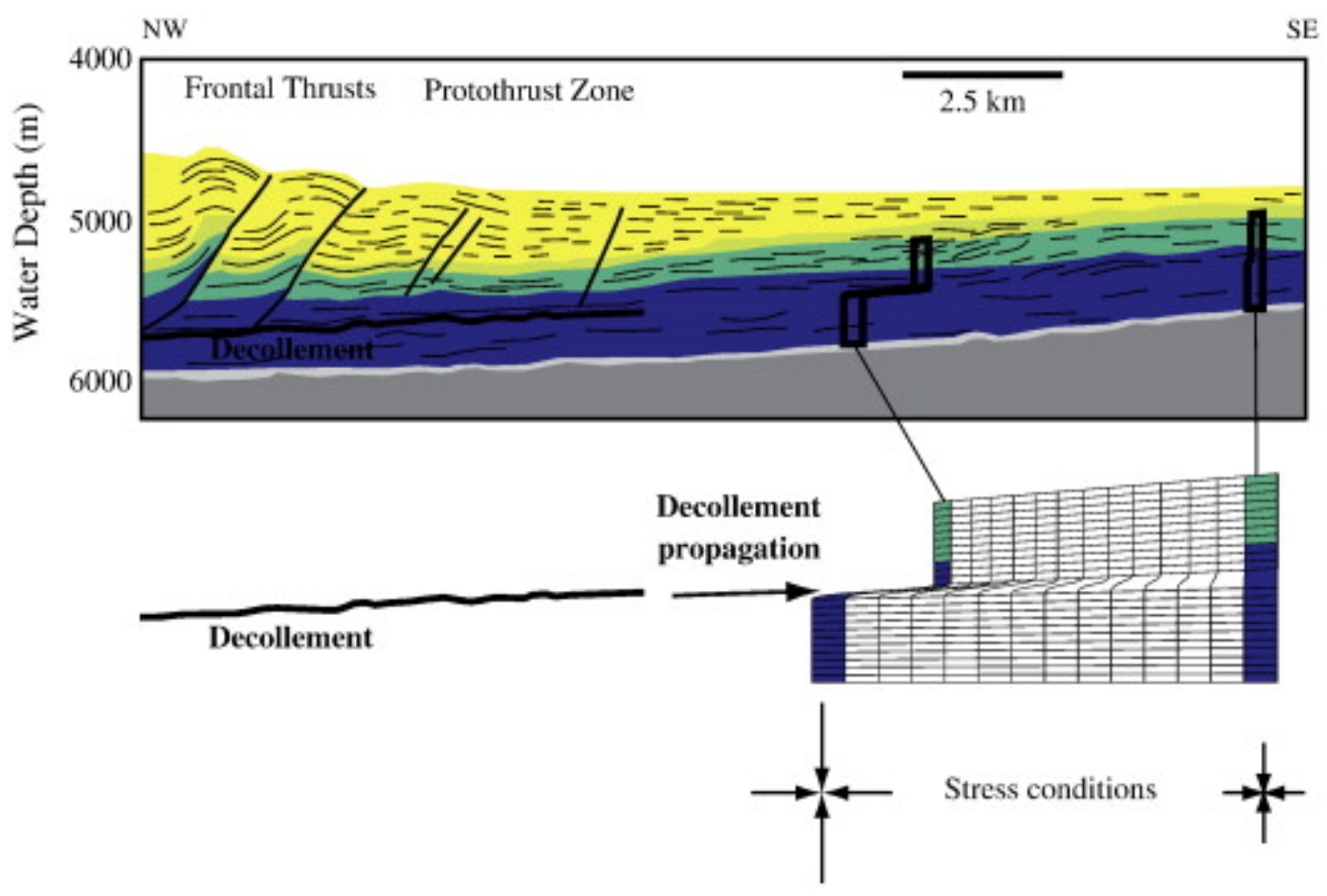


Figure 8: Evolution with depth of magnetic foliation parameter F in Site 1173. F, defined as $\frac{\mathbf{K}_{\text {int }}}{\mathbf{K}_{\text {mIn l:..l }}} \quad(\mathbf{F} \geq \mathbf{1}, 1=$ no magnetic foliation (Hrouda, 1982)), reflects the bulk strain generated by compaction from vertical loading.

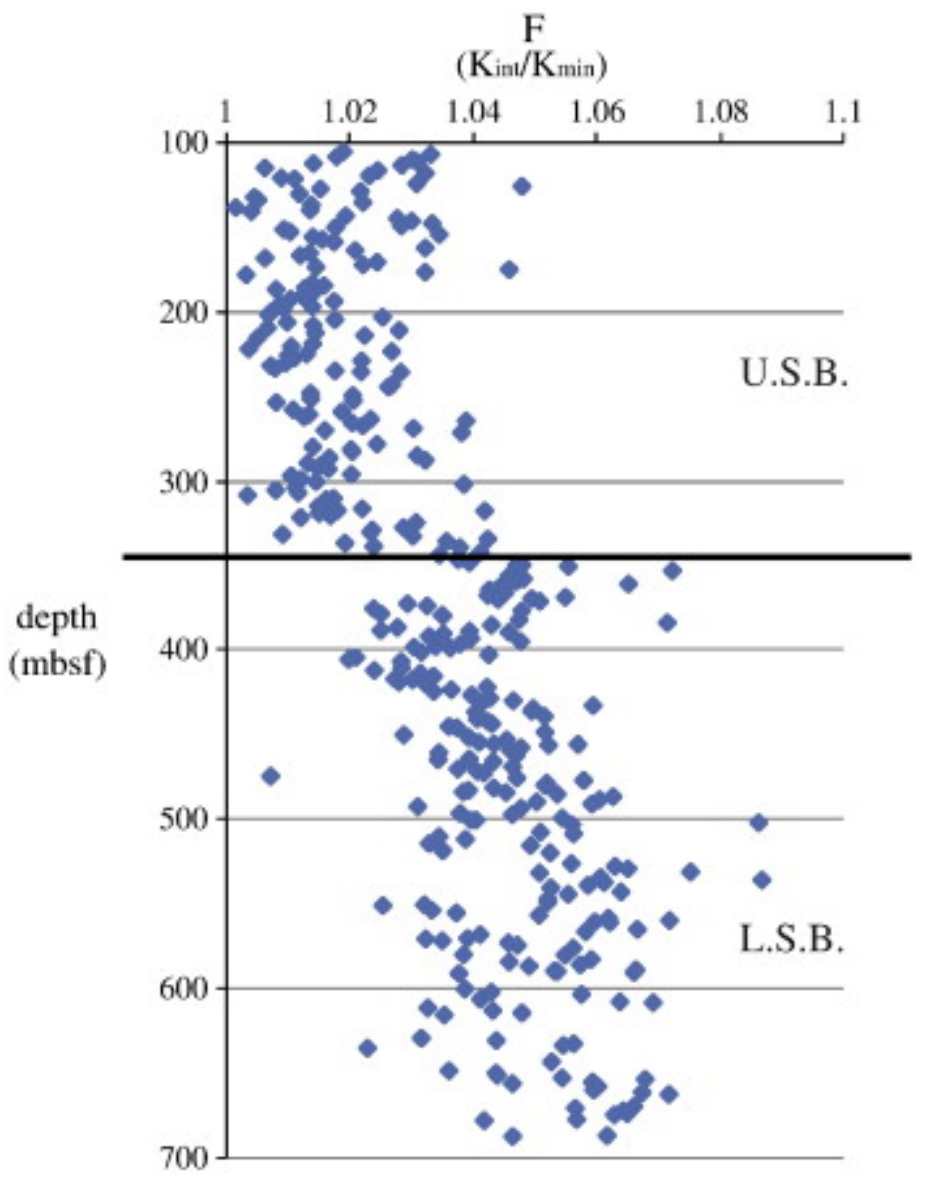

Figure 9: Evolution of $\mathbf{P}_{\mathrm{p}}$ (hence $\mathbf{P}_{\text {eff }}$ ) within a sedimentary column of hemipelagic material (low permeability, dark gray) submitted to rapid loading by a layer of trench turbidites (high permeability, light gray), inspired from the model by Le Pichon and Henry (1992) and Le Pichon et al. (1993). (A) Initial pore pressure distribution in the hemipelagic column (thick gray line), comprised between hydrostatic (dashed black line) and lithostatic (thin black line) pressure profiles. (B) Case of instantaneous 
compaction in the hemipelagites (simplification of Le Pichon and Henry (1992) and Le Pichon et al. (1993)'s model): Upon rapid loading by the turbidites at $\mathbf{t}_{0}$ (thick black curve), the low permeability of the hemipelagites strongly inhibits water outflow and adjustement of the porosity. All the load is transmitted by the solid skeleton to the pore fluid throughout the column, so that pore fluid pressure profile is simply translated (grey arrows) and a minimum in effective pressure develops at the turbidite-hemipelagite transition. Upward flow of water from the hemipelagites enables progressive equilibration (e.g. $\boldsymbol{t}_{\mathbf{2}}$, thick “dash-point" curve) and results in the downward movement in the minimum in effective pressure at depth. (C) Combination of the simple model B and our experimental results about material response to loading. In this case, the material compaction is not instantaneous (as supposed in B): Upon rapid loading by the turbidites at $\mathbf{t}_{0}$, although, like in (B), porosity adjustement is strongly inhibited by the low permeability, the transmission of the load from the framework to the pore fluid is variable with depth. In the shallow and easily deformable domain of the hemipelagite section, all the load increase is instantaneously transmitted to the fluid (long grey arrows) and the pore fluid pressure increases strongly, while in the deep, hardly deformable domain the solid framework is able to sustain some increase in the load without instantaneously compacting, which results in a much 
smaller transmission of the load increase to the pore fluid (small grey arrows) and lower increase in pore fluid pressure. The time-evolution of the pore pressure profile is in this case the result of the competition between water flow (controlled by permeability profile) and time-dependent compaction (controlled by the mechanical properties of the solid framework), but for slow compaction in the deeper domain of the hemipelagites, the lowest effective pressure is localized in the more deformable upper domain.
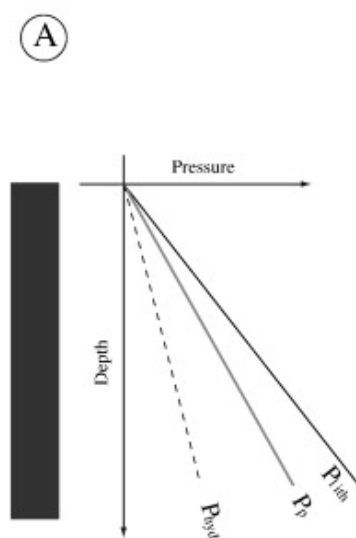

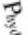

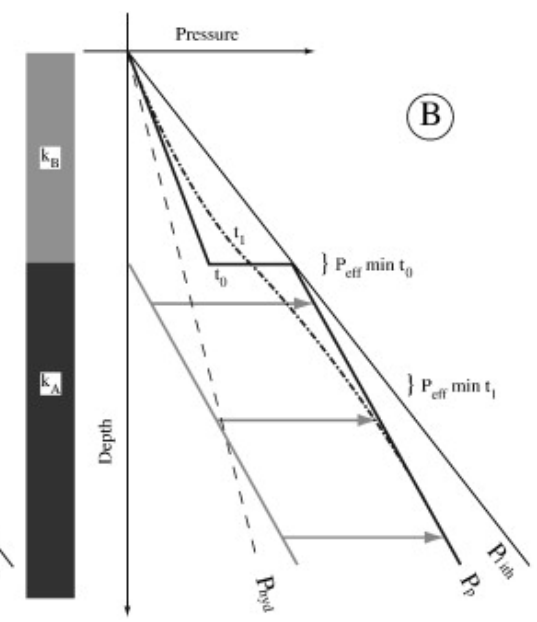

喜

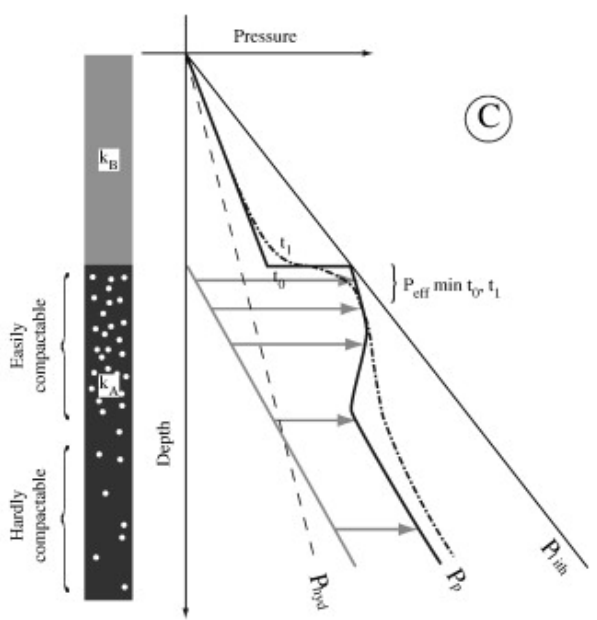

Figure 10:

Evolution of sedimentary material (horizontal velocity, porosity, height) as it passes through a zone of compaction, considered as fixed with respect to material moving from right to left. (A) In the case of vertical compaction, the porosity decrease is accommodated by a reduction in the height of the material column. (B) In the case of horizontal compaction, the decrease in porosity is accompanied, for the sake of solid material conservation, by a decrease in horizontal velocity. Note that if, as a result of 
horizontal compaction, the sediment column height is increased, then the velocity decrease is even larger than in the "minimum" hypothesis chosen here of a column of constant height. (C) If the incoming sediment column is composed of a compactable upper layer, non-compactable lower layer and a transition domain, then the horizontal compaction results in differences in horizontal velocity between lower and upper layers, which lead to shear strain in the transition layer. For (a), (b) and (c), the yellow rectangle corresponds to the initial shape of the column as it enters the zone of compaction, which gets transformed into the red surface after undergoing compaction. 
A
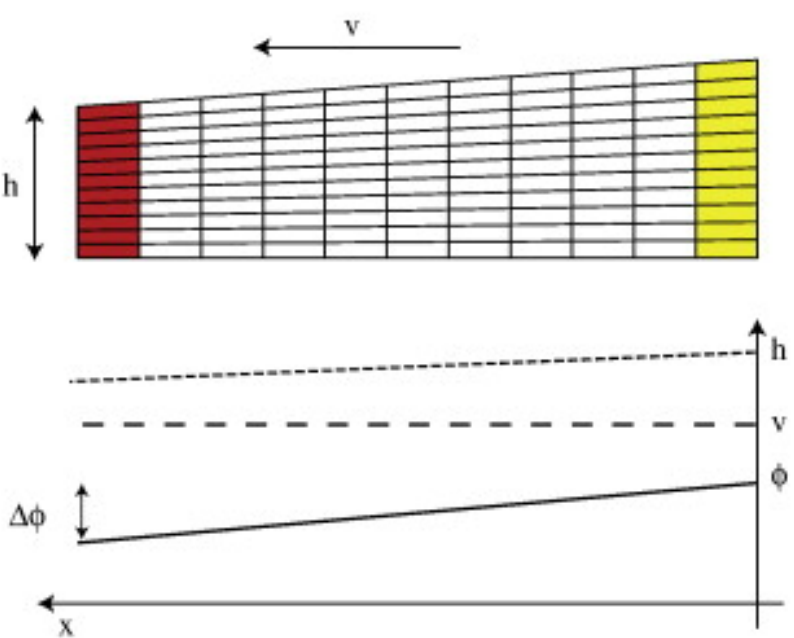

B
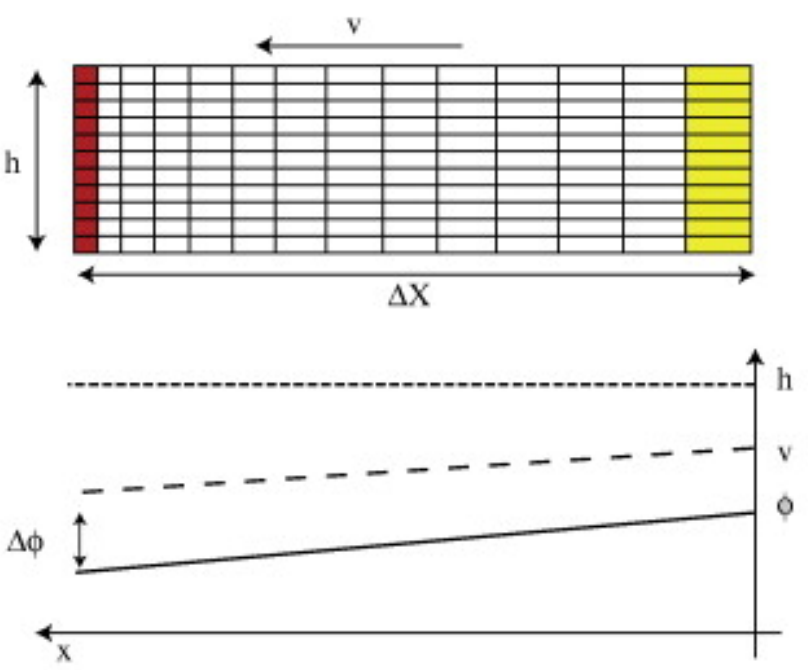

C
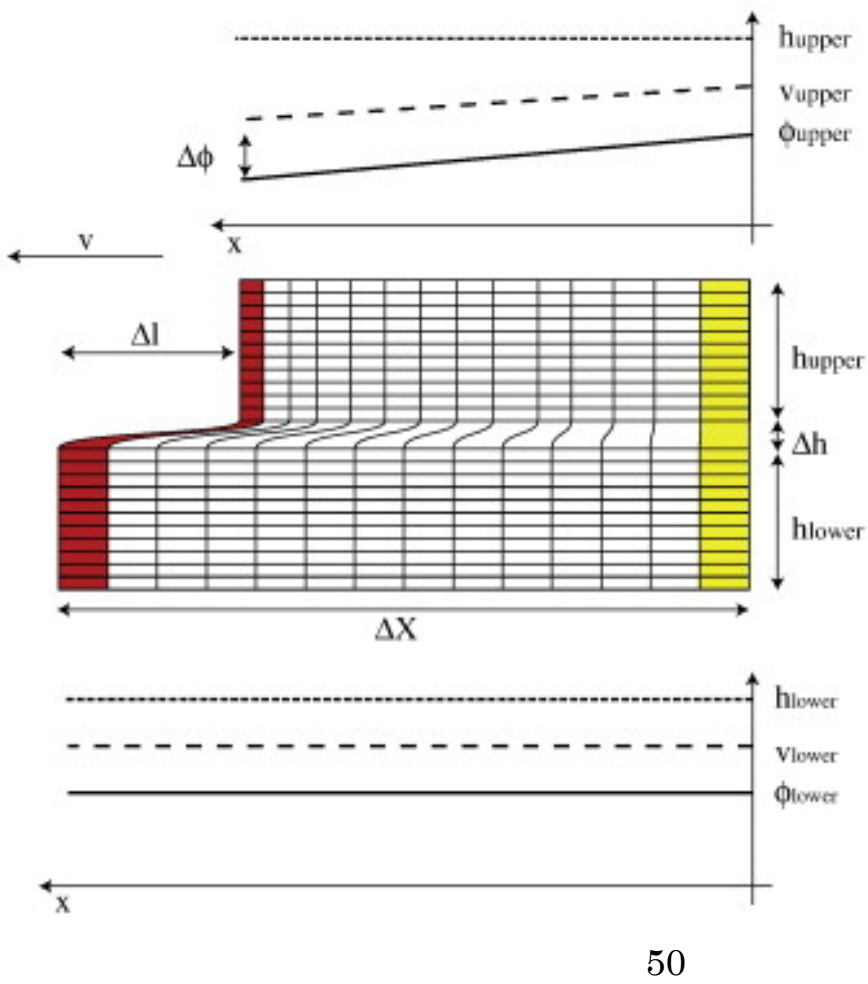


\section{References}

Behrmann, J.H., Kopf, A., 1993. Textures and microfabrics in fine-grained muds and mudstones from site 808, Nankai accretionary prism, in: Hill, I.A., Taira, A., Firth, J.V. (Eds.), Proc. ODP, Sci. Results, Vol. 131, p. doi:10.2973/odp.proc.sr.2131.2106.1993.

Blum, P., 1997. Physical properties handbook: a guide to the shipboard measurement of physical properties of deep-sea cores. ODP Tech. Note 26, http://www-odp.tamu.edu/publications/tnotes/tn26/INDEX.HTM.

Borradaile, G.J., Henry, B., 1997. Tectonic applications of magnetic susceptibility and its anisotropy. Earth Sci. Rev. 42, 49-93.

Brückmann, W., Moran, K., Taylor, E., 1993. Acoustic anisotropy and microfabric development in accreted sediments from the Nankai Trough, in: Hill, I.A., Taira, A., Firth, J.V. (Eds.), Proc. ODP, Sci. Results, Vol. 131, pp. 221-233. doi:210.2973/odp.proc.sr.2131.2121.1993.

Brace, W.F., Walsh, J.B., Frangos, W.T., 1968. Permeability of granite under high pressure. J. Geophys. Res. 80, 2225-2236.

Bray, C.J., Karig, D.E., 1986. Physical properties of sediments from the Nankai Trough, Deep Sea Drilling Project, Leg 87A, Sites 582 and 583, in: Kagami, H., Karig, D.E., Coulbourn, W.T., et al (Eds.), Init. Repts, DSDP, 87, p. doi:10.2973/dsdp.proc.2987.2128.1986.

Brown, K.M., Kopf, A., Underwood, M.B., Weinberger, J.L., 2003. Compositional and fluid pressure controls on the state of stress on the Nankai subduction thrust: A weak plate boundary. Earth Planet. Sci. lett. 214.

Byrne, T., Fisher, D., 1990. Evidence for a weak and overpressured decollement beneath sediment-dominated accretionary prisms. J. Geoph. Res. 95, 9081-9097.

Dahlen, F.A., 1984. Noncohesive Critical Coulomb Wedges - An Exact Solution. J. Geoph. Res. 89, 125-133.

Dahlen, F.A., 1990. Critical taper model of fold-and-thrust belts and accretionary wedges. Annual review of earth and planetary sciences 18, 55-99.

Davis, D., Suppe, J., Dahlen, F.A., 1983. Mechanics of fold-and-thrust belts and accretionary wedges. Journal of Geophysical Research 88, 1153-1172.

Deng, X., Underwood, M., 2001. Abundance of smectite and the location of a plate-boundary fault, Barbados accretionary prism. GSA Bull. 113, 495-507.

Drucker, D.C., 1949. An analysis of the mechanics of metal cutting. J. App. Phys. 20, 1013-1021.

Feeser, V., Moran, K., Bruckman, W., 1993. Stress-regime-controlled yield and strength 
behavior of sediment from the frontal part of the Nankai accretionary prism, in: Hill, I.A., Taira, A., Firth, J.V. (Eds.), Proc. ODP, Sci. Results, 131, pp. 261-273. doi:210.2973/odp.proc.sr.2131.2123.1993.

Henry, P., Le Pichon, X., 1991. Fluid flow along a decollement layer: A model applied to the $16^{\circ} \mathrm{N}$ section of the Barbados accretionary wedge. J. Geophys. Res. 96, 6507-6528.

Housen, B.A., Tobin, H.J., Labaume, P., Leitch, E.C., Maltman, A.J., ODP Leg 156 Shipboard Science Party, 1996. Strain decoupling across the decollement of the Barbados accretionary prism. Geology 24, 127-130.

Hrouda, F., 1982. Magnetic anisotropy of rocks and its application in geology and geophysics. Geophys. Surv. 5, 37-82.

Hunze, S., Wonik, T., 2007. Compaction in the Nankai and Barbados accretionary prisms: New insights from logging-while-drilling data. G-cubed 8, doi:10.1029/2006GC001277.

Karig, D.E., 1993. Reconsolidation tests and sonic velocity measurements of clay-rich sediments from the Nankai Trough, in: Hill, I.A., Taira, A., Firth, J.V. (Eds.), Proc. ODP, Sci. Results, Vol. 131, pp. 247-260. doi:210.2973/odp.proc.sr.2131.2127.2199.

Kim, K.W., Lee, W.Y., Sin, H.C., 1999. A finite-element analysis of machining with the tool edge considered. J. Mater. Process. Tech. 86, 45-55.

Kopf, A., Brown, K.M., 2003. Friction experiments on saturated sediments and their implications for the stress state of the Nankai and Barbados subduction thrusts. Mar. Geol. 202, 193-210.

Le Pichon, X., Henry, P., 1992. Erosion and accretion along subduction zones: a model of evolution. Proc. Kon. Ned. Akad. v. Wetensch 95, 297-310.

Le Pichon, X., Henry, P., Lallemant, S., 1993. Accretion and erosion in subduction zones: The role of fluids. Annu. Rev. Earth Pl. Sc. 21, 307-331.

Liu, K., Melkote, S.N., 2007. Finite element analysis of the influence of tool edge radius on size effect in orthogonal micro-cutting process. Int. J. Mech. Sci. 49, 650-660.

Moore, G., Park, J.O., Bangs, N.L., Gulick, S.P., Tobin, H.J., Nakamura, Y., Saito, S., Tsuji, T., Yoro, T., Tanaka, H., Uraki, S., Kido, Y., Sanada, Y., Kuramoto, S., Taira, A., 2009. Structural and seismic stratigraphic framework of the NanTroSEIZE Stage 1 transect, in: Kinoshita, M., Tobin, H., Ashi, J., Kimura, G., Lallemant, S., Screaton, E.J., Curewitz, D., Masago, H., Moe, K.T., Expedition 314/315/316 Scientists (Eds.), Proc. IODP, 314/315/316. Integrated Ocean Drilling Program Management International, Inc., Washington, DC, pp. 1-46. doi:10.2204/iodp.proc.314315316.314315102.314312009.

Moore, G.F., Shipley, T.H., Stoffa, P.L., Karig, D.E., Taira, A., Kuramoto, S., Tokuyama, H., Suyehiro, K., 1990. Structure of the Nankai Trough accretionary zone from multichannel seismic-reflection data. J. Geophys. Res. 95, 8753-8765. 
Moore, G.F., Taira, A., Klaus, A., Becker, L., Boeckel, B., Cragg, B.A., Dean, A., Fergusson, C.L., Henry, P., Hirano, S., Hisamitsu, T., Hunze, S., Kastner, M., Maltman, A.J., Morgan, J.K., Murakami, Y., Saffer, D.M., Sanchez-Gomez, M., Screaton, E.J., Smith, D.C., Spivack, A.J., Steurer, J., Tobin, H.J., Ujiie, K., Underwood, M.B., Wilson, M., 2001. New insights into deformation and fluid flow processes in the Nankai Trough accretionary prism: Results of Ocean Drilling Program Leg 190. Geochemistry Geophysics Geosystems 2, 2001 GC000166.

Moore, G.F., Mikada, H., Moore, J.C., Becker, K., Taira, A., 2005. Legs 190 and 196 synthesis: Deformation and fluid flow processes in the Nankai Trough accretionary prism, in: Mikada, H., Moore, G.F., Taira, A., Becker, K., Moore, J.C., Klaus, A. (Eds.), Proc. ODP, Sci. Results, 190/196, pp. 1-26. doi:10.2973/odp.proc.sr.190196.190201.192005.

Moore, J.C., Klaus, A., Bangs, N.L., Bekins, B.A., Bucker, C.J., Bruckman, W., Erickson, S.N., Hansen, O., Horton, T., Ireland, P., Olson Major, C., Moore, G.F., Peacock, S., Saito, S., Screaton, E.J., Shimeld, J.W., Henry Stauffer, P., Taymaz, T., Teas, P.A., Tokunaga, T., 1998. Consolidation patterns during initiation and evolution of a plate-boundary decollement zone: Northern Barbados accretionary prism. Geology 26, 811-814.

Moore, J.C., 2000. Synthesis of Results: Logging While Drilling, Northern Barbados Accretionary Prism, in: Moore, J.C., Klaus, A., Bangs, N.L., Bekins, B.A., Bruckman, W., Bucker, C.J., Erickson, S.N., Hansen, O. (Eds.), Proc. ODP,Sci. Results, 171A, p. doi:10.2973/odp.proc.sr.2171A.2101.2000.

Moran, K., Bruckmann, W., Feezer, V., Campanella, R.G., 1993. In-situ stress conditions at Nankai Trough, site 808, in: Hill, I.A., Taira, A., Firth, J.V. (Eds.), Proc. ODP, Sci. Results, Vol. 131, pp. 283-291. doi:210.2973/odp.proc.sr.2131.2129.1993.

Morgan, J.K., Karig, D.E., Maniatty, A., 1994. The estimation of diffuse strains in the toe of the western Nankai accretionary prism: A kinematic solution. J. Geophys. Res. 99, 7019-7032.

Morgan, J.K., Karig, D.E., 1995. Decollement processes at the Nankai accretionary margin, southeast Japan: Propagation, deformation and dewatering. J. Geophys. Res. 100, $15,221-215,231$.

Morgan, J.K., Ask, M.V.S., 2004. Consolidation state and strength of underthrust sediments and evolution of the décollement at the Nankai accretionary margin: Results of uniaxial reconsolidation experiments. J. Geophys. Res. 109, doi:10.1029/2002JB002335.

Nur, A., Mavko, G., Dvorkin, J., Galmudi, D., 1998. Critical porosity: A key to relating physical properties to porosity in rocks. The Leading Edge, 357-362.

Owens, W.H., 1993. Magnetic fabric studies of samples from hole 808C, Nankai Trough, in: Hill, I.A., Taira, A., Firth, J.V. (Eds.), Proc. ODP, Sci. Results, Vol. 131, p. doi:10.2973/odp.proc.sr.2131.2130.1993. 
Raimbourg, H., Hamano, Y., Saito, S., Kinoshita, M., Kopf, A., in press. Acoustic and mechanical properties of Nankai accretionary prism core samples. G-cubed, doi:10.1029/2010GC003169.

Saffer, D.M., Bekins, B.A., 1998. Episodic fluid flow in the Nankai accretionary complex: Timescale, geochemistry, flow rates and fluid budget. J. Geophys. Res. 103, 30,351-330,370.

Saito, S., Goldberg, D., 2001. Compaction and dewatering processes of the oceanic sediments in the Costa Rica and Barbados subduction zones: estimates from in situ physical property measurements. Earth Planet. Sci. lett. 191, 283-293.

Screaton, E.J., Saffer, D.M., Henry, P., Hunze, S., Leg 190 Shipboard Party, 2002. Porosity loss within the underthrust sediments of the Nankai accretionary complex: Implications for overpressures. Geology 30, 19-22.

Shi, Y., Wang, C.-Y., 1985. High pore pressure generation in sediments in front of the Barbados ridge complex. Geoph. Res. Lett. 12, 773-776.

Shi, Y., Wang, C.-Y., 1988. Generation of high pore pressures in accretionary prisms: Inferences from the Barbados subduction complex. J. Geophys. Res. 93, 8893-8910.

Shipboard Scientific Party, 1998. Site 1048, in: Moore, J.C., Klaus, A., Bangs, N.L., Bekins, B.A., Bruckman, W., Bucker, C.J., Erickson, S.N., Hansen, O. (Eds.), Proc. ODP, Init. Repts., 171A, p. doi:10.2973/odp.proc.ir.2171a.2107.1998.

Shipboard Scientific Party, 2001a. Leg 190 Summary, in: Moore, G.F., Taira, A., Klaus, A., Becker, L., Boeckel, B., Cragg, B.A., Dean, A., Fergusson, C.L., Henry, P., Hirano, S., Hisamitsu, T., Hunze, S., Kastner, M., Maltman, A.J., Morgan, J.K., Murakami, Y., Saffer, D.M., Sanchez-Gomez, M., Screaton, E.J., Smith, D.C., Spivack, A.J., Steurer, J., Tobin, H.J., Ujiie, K., Underwood, M.B., Wilson, M. (Eds.), Proc. ODP, Init. Repts, College Station, TX (Ocean Drilling Program), p. doi:10.2973/odp.proc.ir.2190.2101.2001.

Shipboard Scientific Party, 2001b. Site 1173, in: Moore, G.F., Taira, A., Klaus, A., Becker, L., Boeckel, B., Cragg, B.A., Dean, A., Fergusson, C.L., Henry, P., Hirano, S., Hisamitsu, T., Hunze, S., Kastner, M., Maltman, A.J., Morgan, J.K., Murakami, Y., Saffer, D.M., Sanchez-Gomez, M., Screaton, E.J., Smith, D.C., Spivack, A.J., Steurer, J., Tobin, H.J., Ujiie, K., Underwood, M.B., Wilson, M. (Eds.), Proc. ODP, Init. Repts, College Station, TX (Ocean Drilling Program), pp. 1-147. doi:110.2973/odp.proc.ir.2190.2104.2001.

Shipley, T.H., Stoffa, P.L., Dean, D.F., 1990. Underthrust sediments, fluid migration paths, and mud volcanoes associated with the accretionary wedge off Costa Rica: Middle America Trench. J. Geophys. Res. 95, 8743-8752.

Spinelli, G., Mozley, P.S., Tobin, H.J., Underwood, M.B., Hoffman, N.W., Bellew, G.M., 2007. Diagenesis, sediment strength, and pore collapse in sediment approaching the Nankai Trough subduction zone. GSA Bull. 119, 377-390. 
Steurer, J.F., Underwood, M., 2005. Clay mineralogy of mudstones from the Nankai Trough references sites 1173 and 1177 and frontal accretionary prism site 1174, in: Mikada, H., Moore, G.F., Taira, A., Becker, K., Moore, J.C., Klaus, A. (Eds.), Proc. ODP, Sci. Results, 190/196, pp. 1-37. doi:10.2973/odp.proc.sr.190196.190211.192003.

Sunderland, E.B., Morgan, J.K., 2004. Microstructural variations in sediments from the toe of the Nankai accretionary prism: Results of scanning electron microscope analysis, in: Mikada, H., Moore, G.F., Taira, A., Becker, K., Moore, J.C., Klaus, A. (Eds.), Proc. Ocean Drill. Program, Sci. Results [online], 190/196, pp. 1-27. doi:10.2973/odp.proc.sr.190196.190212.192004.

Taira, A., Hill, I., Firth, j., Berner, U., Briickmann, W., Byrne, T., Chabernaud, T., Fisher, A., Foucher, j.-p., Gamo, T., Gieskes, j., Hyndman, R., Karig, D., Kastner, M., Kato, Y., Lallemant, S., Lu, R., Maltman, A., Moore, G., Moran, K., Olaffson, G., Owens, W., Pickering, K., Siena, F., Taylor, E., Underwood, M., Wilkinson, C., Yamano, M., Zhang, J., 1992. Sediment deformation and hydrogeology of the Nankai Trough accretionary prism: Synthesis of shipboard results of ODP Leg 131. Earth Planet. Sci. Lett. 109, 431-450.

Tobin, H.J., Saffer, D.M., 2009. Elevated fluid pressure and extreme mechanical weakness of a plate boundary thrust, Nankai Trough subduction zone. Geology 37, 679-682.

Ujiie, K., Hisamitsu, T., Taira, A., 2003. Deformation and fluid pressure variation during initiation and evolution of the plate boundary decollement zone in the Nankai accretionary prism. J. Geophys. Res. 108, 2398.

Underwood, M.B., Pickering, K., Gieskes, J.M., Kastner, M., Orr, K., 1993. Sediment geochemistry, clay mineralogy, and diagenesis: A synthesis of data from Leg 131, Nankai Trough, in: Hill, I.A., Taira, A., Firth, J.V. (Eds.), Proc. ODP, Sci. Results, 131, p. doi:10.2973/odp.proc.sr.2131.2137.1993.

Uyeda, S., Kanamori, H., 1979. Backarc opening and the mode of subduction. J. Geophys. Res. 84, 1049-1106.

Von Huene, R., Scholl, D.W., 1991. Observations at convergent margins concerning sediment subduction, subduction erosion, and the growth of continental crust. Rev. Geophys. 29, 279-316.

Westbrook, G.K., Smith, M.J., Peacock, J.H., Poulter, M.J., 1982. Extensive underthrusting of undeformed sediment beneath the accretionary complex of the Lesser Antilles subduction zone. Nature 300, 625-628.

Woon, K.S., Rahman, M., Fang, F.Z., Neo, K.S., Liu, K., 2008. Investigations of tool edge radius effect in micromachining: A FEM simulation approach. J. Mater. Process. Tech. 195, 204-211.

Wu, J., Liu, Z., 2009. Modeling of flow stress in orthogonal micro-cutting process based on 
strain gradient plasticity theory. Int. J. Adv. Manuf. Technol., DOI 10.1007/s00170-00009-02049-00170. 